
PENAL CULPOSADEL OFICIAL DE CUMPLIMIENTO EN EL SISTEMA FINANCIERO (ARTÍCULO $5^{\circ}$ DEL DECRETO LEGISLATIVO No 1106 - LUCHA EFICAZ CONTRA EL LAVADO DE ACTIVOS Y OTROS DELITOS RELACIONADOS A LA MINERÍA ILEGAL Y CRIMEN ORGANIZADO)

Trabajo de investigación para optar el Grado Académico de Maestro en Derecho Empresarial

Carlos Alberto Wiesse Asenjo

Código 20040049

Asesor

Dino Carlos Caro Coria

Lima - Perú

Enero de 2019 


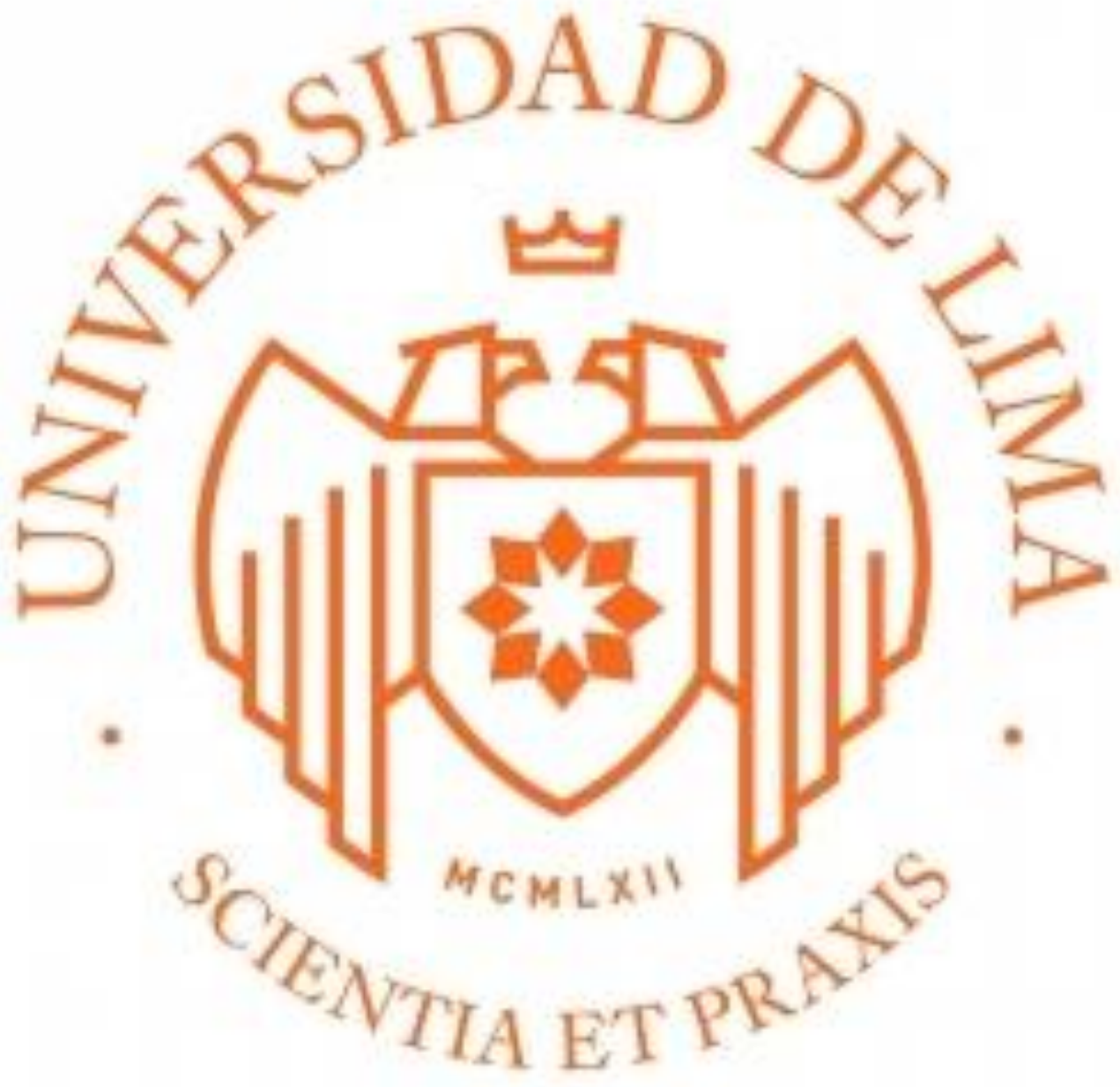


MODIFICACIÔNDE LA RESPONSABILIDAD PENAL CULPOSA DEL OFICIAL DE CUMPLIMIENTO ENEL SISTEMA

FINANCIERO (ARTÍCULO 5 DEL DECRETO

LEGISLATIVO N ${ }^{\circ} 1106$ - LUCHA EFICAZ

CONTRA EL LAVADO DE ACTIVOS Y

OTROS DELITOS RELACIONADOS A LA

MINERÍA ILEGAL Y CRIMEN

ORGANIZADO) 


\section{TABLA DE CONTENIDOS}

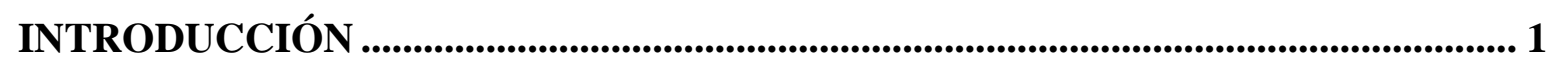

CAPITULO I: INVESTIGACIÓN Y OBJETIVOS DEL TRABAJO................................ 4

1.1. Plan de Investigación.................................................................................. 4

1.1.1. Selección del tema de investigación: criterios para la elección, fuentes, relevancia y originalidad................................................................................... 4

1.1.1.1. Tema de investigación ................................................................. 4

1.1.1.2. Criterios para Ta elección ..................................................................... 4

1.1.1.3. Relevancia y Originalidad ................................................................. 5

1.1.2. Identificación del problema: por medio de preguntas a responder, estado de la cuestión, investigación preliminar, justificación/importancia............................. 7

1.1.2.1. Identificación del problema ................................................................ 7

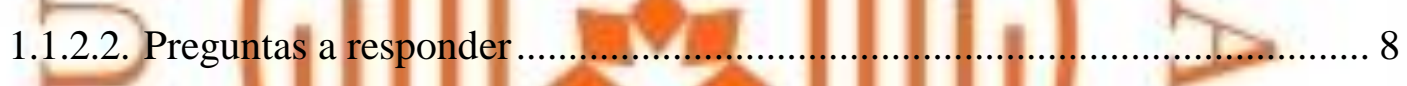

1.1.2.3. Estado de la cuestión ........................................................................ 8

1.1.2.4. Investigación preliminar ....................................................................... 9

1.1.2.5. Justificación/Importancia................................................................... 11

1.2.. Objetivos de la investigación: aportes de la investigación, objetivo central más

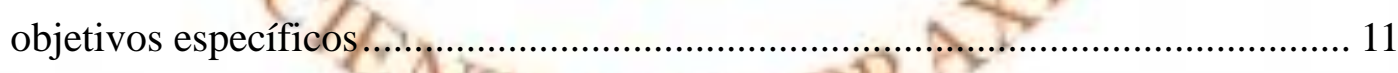

1.2.1. Objetivos de la investigación ............................................................. 12

1.2.2. Aportes de la investigación......................................................................... 12

1.2.3. Objetivo central más objetivos específicos ................................................... 12

1.3. Hipótesis de la investigación: Respuestas tentativas abiertas a verificación durante la investigación/descarte/confirmación ..................................................... 13

1.4. Fuentes de investigación.................................................................................. 13

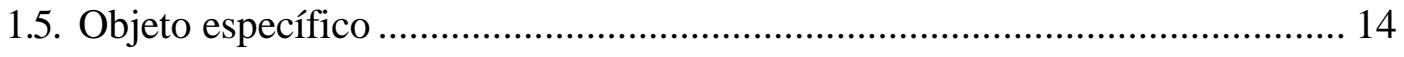


1.6. Contenido.

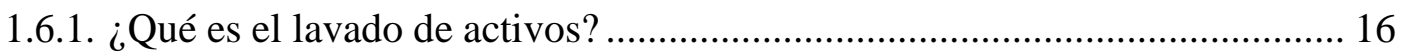

1.6.2. Etapas del lavado de activos .............................................................. 19

1.6.3. Factores de riesgo de lavado de activos............................................... 20

1.7. Marco Nacional e Internacional del lavado de activos ................................. 23

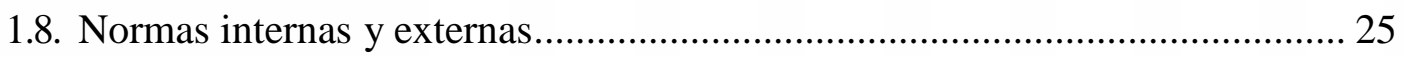

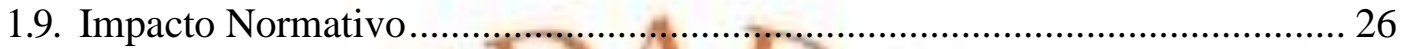

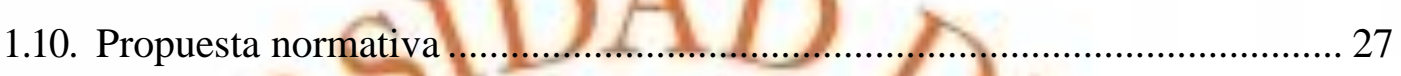

1.11. Responsabilidad Penal del Oficial de Cumplimiento ................................ 31

1.12. Consecuencias de la Responsabilidad Penal............................................ 32

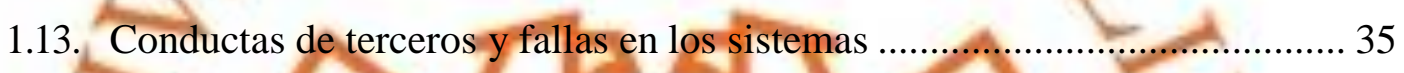

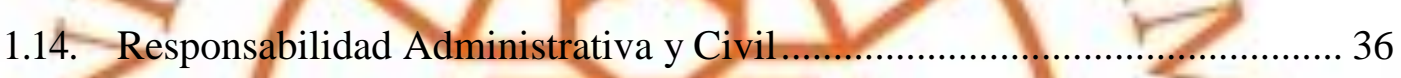

1.15. Conclusiones del Primer Capítulo ........................................................... 39

CAPITULO II: EL ROL DE LAS AUTORIDADES EN LOS SISTEMAS DE

PREVENCIÓN DE LAVADO DE ACTIVOS ............................................................. 41

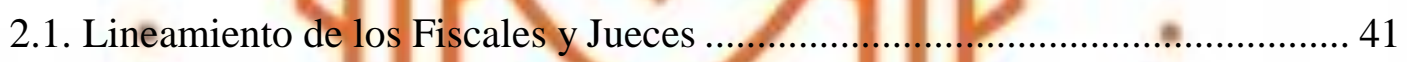

2.1.1. Deber de reserva y confidencialidad................................................ 41

2.1.2. Medidas de seguridad para el Oficial de Cumplimiento ............................. 43

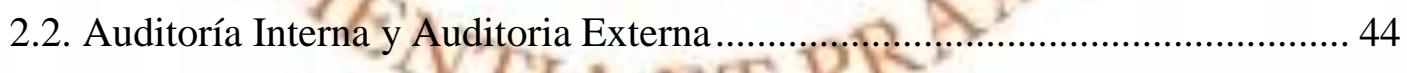

2.2.1. Las evaluaciones al sistema de prevención de lavado de activos ................ 44

2.2.2. Responsabilidad de los auditores internos y externos............................... 45

2.3. La Unidad de Inteligencia Financiera ..................................... 49

2.3.1. Prevención del sistema de lavado de activos .......................................... 50

2.3.2. Protección al Oficial de Cumplimiento ............................................... 51

2.4. Conclusiones del segundo capítulo .................................................... 54 


\section{CAPITULO III: CÓMO MEJORAR LOS SISTEMAS DE PREVENCIÓN DE}

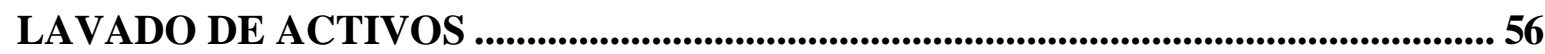

3.1. Análisis y mejoras como resultado de la modificación de la responsabilidad penal del Oficial de Cumplimiento........................................................................ 56

3.2. Mejoras en el Sistema de Prevención de Lavado de Activos ............................ 57

3.3. Conclusiones del tercer capítulo................................................................. 71

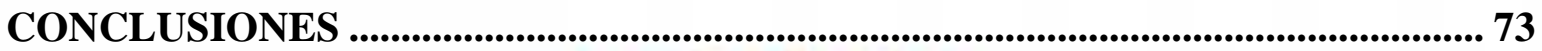

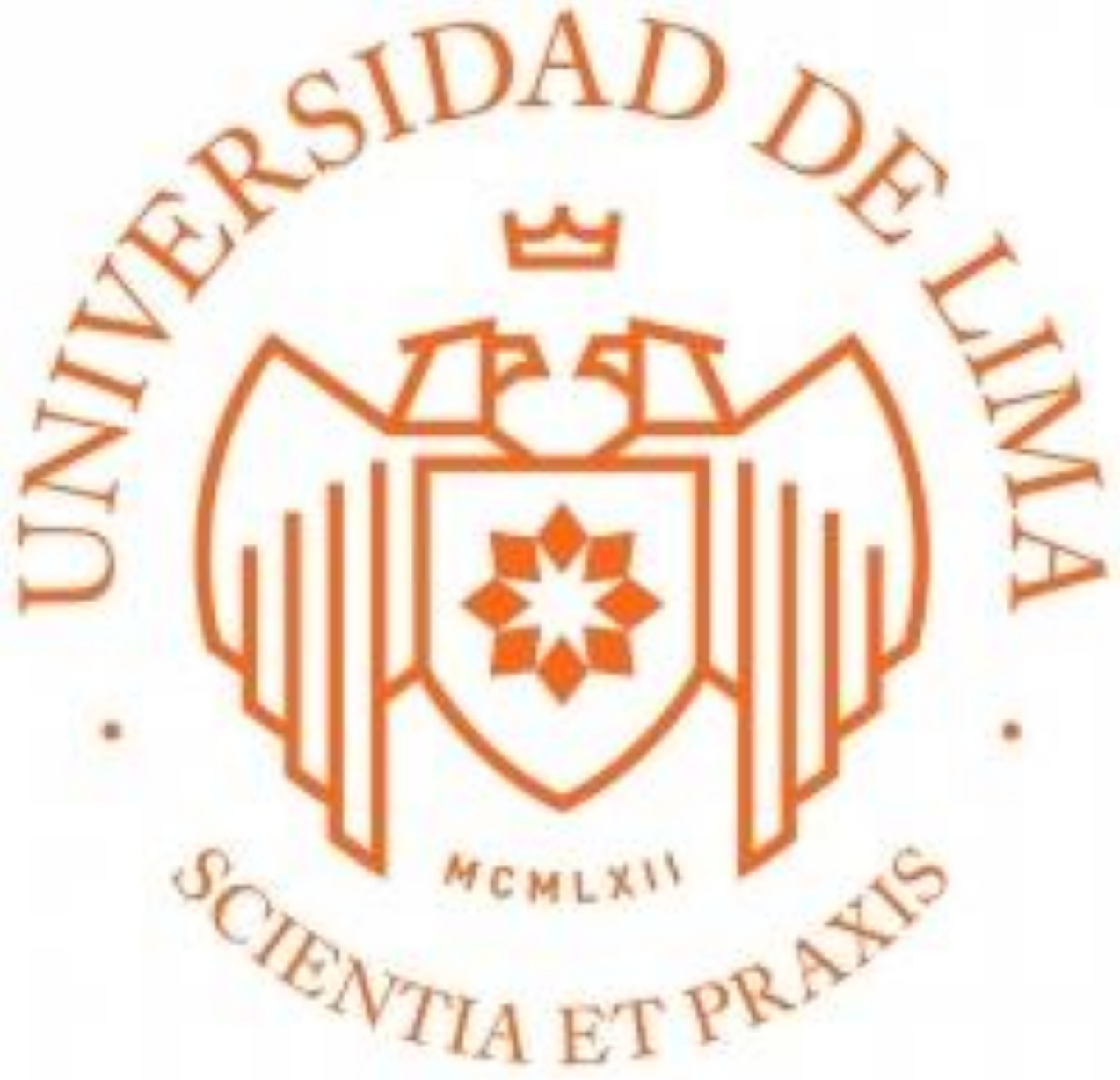




\section{INTRODUCCIÓN}

El presente trabajo constituye un acercamiento al estudio y análisis de la responsabilidad tripartita del Oficial de Cumplimiento en el sistema financiero peruano y el impacto que tiene su labor no solo en los sistemas de prevención de lavado de activos y del financiamiento del terrorismo de las instituciones financieras, sino también la importancia en el rol de la sociedad, aun cuando sus funciones no sean visibles para todos. En el presente trabajo se presentarán alternativas que puedan servir para un posible cambio normativo en cuanto a la responsabilidad penal del Oficial de Cumplimiento.

En la actualidad mundial vivimos una crisis plagada de males como son: la corrupción, las drogas, el terrorismo, trata de personas, la contaminación ambiental y muchos otros delitos precedentes ligados al lavado de activos y al financiamiento del terrorismo. Dentro de este contexto, vemos día a día la destrucción de la humanidad, al presenciar en las noticias los tipos de organizaciones criminales ligadas al narcotráfico y terrorismo.

En América latina, en los años 80 hemos sido testigos que personajes colombianos se han apoderado de la región, con la cultivación y producción de la cocaína, arrojando índices altísimos de corrupción e incremento de la criminalidad

Luego de la extinción de los carteles colombianos hemos vivido el nacimiento de organizaciones criminales mexicanas que son las nuevas tendencias criminales de nuestra región y que ponen a nuestro país como primer productor de droga en el mundo, superando a Bolivia y Colombia que eran los países que siempre mantenían la supremacía de ese nefasto mercado.

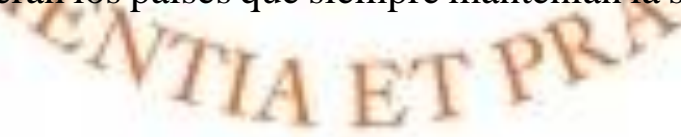

En ese orden de ideas, al realizar un rápido repaso sobre el pasado del narcotráfico en nuestra región, se considera de vital importancia la tarea del Oficial de Cumplimiento, pues no solo se trata de prevenir y cumplir con las normas que imponen los reguladores sino que mucho más importante es la actuación principal ante nuestra sociedad, debido a que la principal fuente de información para detectar las operaciones inusuales o 
sospechosas nacen en el sistema financiero, pues la actividad criminal para subsistir tiene la necesidad de blanquear el dinero para llevar a cabo toda su maquinaria criminal.

En el campo del terrorismo, el Perú ha experimentado la crueldad de grupos terroristas que hoy día se encuentran casi exterminados, sin embargo en la coyuntura mundial este delito va en aumento y es ahí donde las instituciones financieras del primer mundo juegan un rol vital para eliminar estos grupos terroristas pues mediante sus sistemas de transacciones de dinero se pueden detectar transferencias bancarias dirigidas para estos objetivos, sin embargo es difícil detectar la actividad ilícita en el terrorismo pues en la mayoría de casos la financiación del terrorismo proviene de origen de dinero lícito.

Asimismo, vemos como la corrupción en nuestro país es una enfermedad inherente a nuestra idiosincrasia, desde el funcionario público de menor rango hasta las más altas esferas como lo son los Presidentes de la República, la corrupción se encuentra inherente en todos los ámbitos, que por cierto no solo es un mal que adolece el sistema público, sino también las empresas privadas, como lo hemos visto con esta empresa brasilera que junto a sus secuaces de grandes empresas constructoras peruanas han saqueado las arcas de nuestro país inflando obras y llevándose todo el dinero de los peruanos.

Entonces, ¿qué podemos hacer ante estos delitos tan nocivos para nuestro país y para el mundo? No tengo una sola respuesta, pienso que se debe afianzar la educación pero no como un tema político de cada Presidente en sus mandatos, sino que exista el compromiso de todos, sector privado y sus principales líderes y el sector público con una política que contenga un plan a futuro y no uno corto que cambie cuando ingresa un nuevo gobierno.

En ese sentido, debe existir una verdadera educación pública y privada donde cultiven los valores y principios que se deben seguir y luego de ello, dictar un marco normativo razonable y que se pueda aplicar, dándole seguridad a las personas que se ven ligados a prevenir este tipo de delitos como lo son los Oficiales de Cumplimiento.

Por otro lado, cabe indicar que este trabajo enmarca las funciones y responsabilidades de un Oficial de Cumplimiento, haciendo hincapié, que como cualquier Sujeto Obligado, los Oficiales de Cumplimiento son trabajadores del sector privado y no se les debe pretender otorgar funciones o asimilar funciones a la de una autoridad policial o 
fiscal, pues el Oficial de Cumplimiento no es un investigador sino que es un ejecutivo dentro de una organización que tiene funciones y responsabilidades pero no como cualquier otro, debido a que pesa sobre él una responsabilidad penal y que en muchos casos una culposa, que es lo que trato de explicar en este trabajo.

Asimismo, fundamento las formas de atenuar tal responsabilidad penal del Oficial de Cumplimiento, con la finalidad de darle mayor seguridad a la labor de prevenir y detectar el lavado de activos dentro de las empresas privadas donde laboran.

Es importante también indicar, que los Bancos y los demás Sujetos Obligados, son empresas privadas que buscan incrementar sus ingresos y tienen objetivos diferentes a los de las autoridades, en ese sentido el sector privado no busca la persecución penal del delito por eso es que el Oficial de Cumplimiento es un ejecutivo bancario y no es una autoridad obligado a perseguir delincuentes que pretender blanquear dinero en las instituciones privadas; es por ello que en el presente trabajo buscà proveer de herramientas para lograr, si fuera posible, una modificación normativa sobre la responsabilidad penal del Oficial de Cumplimiento.

\section{Información complementaria:}

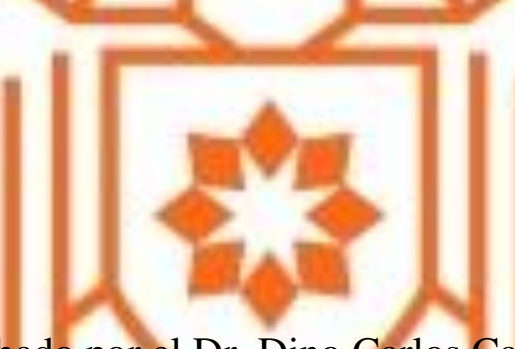

- Documento revisado y aprobado por el Dr. Dino Carlos Caro Coria, asesor asignado a la tesis por la Maestría de Derecho Empresarial de la Universidad de Lima.

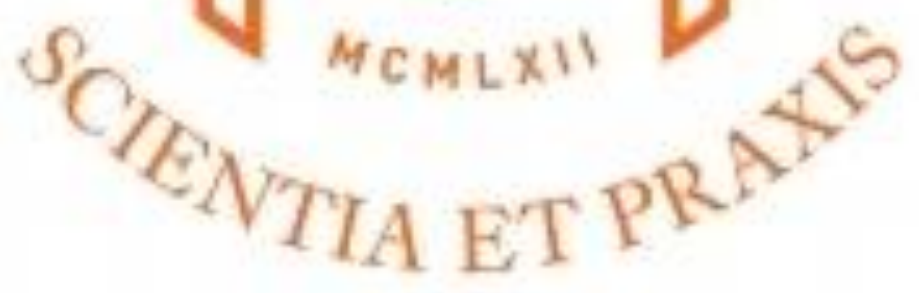




\section{CAPITULO I: INVESTIGACIÓN Y OBJETIVOS DEL TRABAJO}

\subsection{Plan de Investigación}

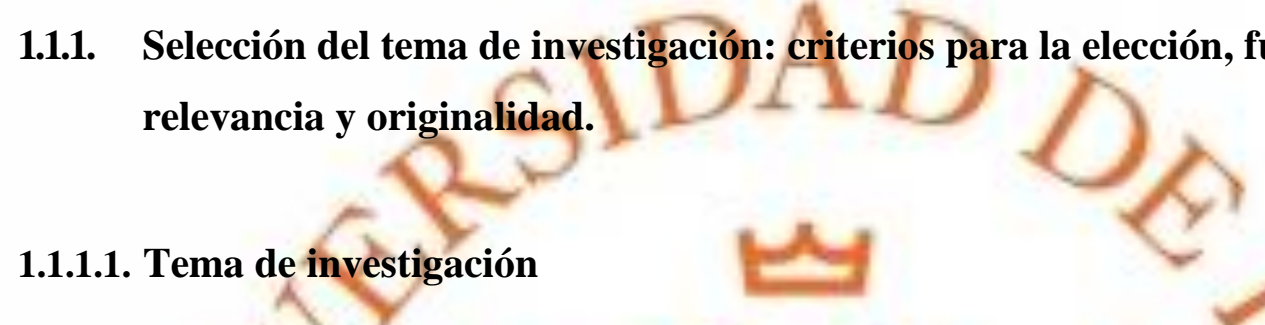

Modificación de la Responsabilidad Penal Culposa del Oficial de Cumplimiento en el Sistema Financiero Peruano.

\subsubsection{Criterios para la elección}

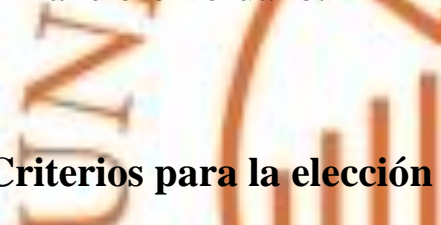

Se ha determinado el tema elegido debido a que de acuerdo a mi experiencia laboral, el Oficial de Cumplimiento de los Bancos no debería cargar con una responsabilidad penal culposa. Esto se fundamenta, en razón de la consecuencia jurídica de la comisión de un hecho tipificado en la ley penal pues no puede ser responsable una persona que no cometió el hecho punible, es decir si no existe voluntad óánimo del Oficial de Cumplimiento de incumplir y de mitigar el delito de lavado de activos, no debería existir un resultado desfavorable para él; en ese orden de ideas, si otro Funcionario del Banco comete negligencia u omite la debida diligencia con los clientes que aparentemente se encuentren lavando dinero dentro de su institución, si justifica la sanción penal en ese supuesto.

En consecuencia a ello, el no existir un comportamiento doloso por parte del Oficial de Cumplimiento, éste no puede ser responsable de sanciones que causen resultados en sanciones penales. 
Por otro lado, el criterio de elección para el presente trabajo, he tomado en consideración que todos los delitos tienen un bien jurídico protegido, pero para el caso de lavado de activos, especialmente el delito de omisión de operaciones sospechosas, no contempla un bien jurídico protegido, entonces no se puede imputar una responsabilidad a un funcionario bancario, cuando éste tiene una labor administrativa.

Para tal fin, existe la Superintendencia de Banca, Seguros y AFP, quien es el ente gubernamental que regula administrativamente la función de los Oficiales de Cumplimiento. En otros países como en Brasil, el omitir reportar una operación sospechosa es considerado como una falta administrativa, en España no existe delito de no reportar, ya que se encuentra incluido dentro del delito de lavado de activos.

Cabe indicar, que la eliminación de la Responsabilidad culposa del Oficial de Cumplimiento fortalecería el Sistema de Prevención de Lavado de Activos y Financiamiento del Terrorismo, en el sentido de que los Oficiales de Cumplimiento no tendrán temor de reportar operaciones sospechosas ante las represalias a las que hoy se ven expuestos.

Asimismo los Funcionarios de Negocios ayudarían a la labor de prevención pues no estarían expuestos a sanciones penales y estarían en la libertad de ayudar al Oficial de Cumplimiento en sus labores de mitigación de riesgos de lavado de activos.

Evidentemente debe existir una responsabilidad penal para los Oficiales de Cumplimiento solo para los casos de dolo, es decir cuando exista conocimiento y voluntad de realizar el tipo objetivo de un delito, en este caso aceptar el lavado de activos dentro de una institución, por tanto los elementos que integran este acto serían, el elemento intelectual o cognoscitivo y el elementó volitivo.

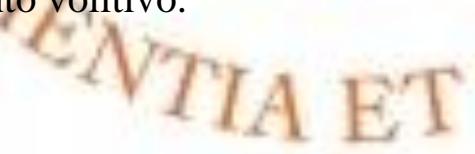

\subsubsection{Relevancia y Originalidad}

Dado la importancia de evitar que el delito de lavado de activos siga creciendo en nuestro país, es relevante que se dicten normas claras y con sustentos reales que ayuden a mitigar los riesgos de lavado en las instituciones financieras, es por ello que en el presente trabajo trato de fundamentar mi posición para lograr eliminar la responsabilidad penal de Oficial 
de Cumplimento constituyendo de esta manera un tema original e importante para las labores de los citados funcionarios.

En ese sentido, dado que el Oficial de Cumplimiento no ha cometido el ilícito penal por ende debe quedar excluido de cualquier responsabilidad penal que se presente dentro de su institución, pues para ello el Banco tiene implementado un Sistema de Prevención de Lavado de Activos y del Financiamiento del Terrorismo - SPLAFT, en el cual el Oficial de Cumplimiento es el principal responsable en implementar y cumplir el SPLAFT, pero ello no conlleva a que otros Funcionarios del Banco puedan cometer actos ilícitos y en consecuencia de ello, el Oficial de Cumplimiento se vea involucrado en actos que otros cometieron en perjuicio de su institución.

Es por ello, la importancia del presente trabajo pues al eliminar la responsabilidad penal para los Oficiales de Cumplimiento, éstos realizarían sus labores sin miedo a ser juzgados por actos que otros cometieron o simplemente por negligencia de terceros.

Por/tanto, al eliminar la responsabilidad penal se mejoraría la eficiencia en las actividades de prevención, pues los Oficiales de Cumplimiento mejorarían los reportes de operaciones sospechosas que envían a la Unidad de Inteligencia Financiera-UIF, en el sentido de que no tendrían temor a represalias sobre la información que reportan de los clientes.

Finalmente, el presente trabajo es original dado que en el Perú hasta el̂̃ día de hoy no se ha puesto sobre la mesa, la eliminación de la responsabilidad penal del Oficial de Cumplimiento, no obstante a ello encontramos autores que hablan sobre la omisión de no reportar operaciones sospechosas pero no hay autores que tocan directamente la eliminación de la pena para el Oficial de Cumplimiento, ni como tampoco nadie ha indicado cuál es el verdadero rol de los auditores externos, auditor interno y funcionarios comerciales sobre sus conductas de prevención de lavado de activos y del financiamiento del terrorismo.

En ese orden de ideas, el presente trabajo consiste en plantear una mitigación de la pena para el Oficial de Cumplimiento y formalizar las responsabilidades de otros autores dentro de un marco que solo recae sobre el Oficial de Cumplimiento. Asimismo, un tema importante a destacar, es que se promueve la función del Compliance Officer como un ente 
que almacena riesgos de Compliance y no solamente de lavado de activos, es decir el Compliance Officer es el encargado de mitigar los riesgos de lavado de activos, corrupción, terrorismo, legal, fraude entre otros.

En ese sentido, en el Perú el Oficial de Cumplimiento solo se dedica exclusivamente a prevenir el lavado de activos, lo que limitaría sus labores pues los riesgos mencionados también deben abarcar las funciones del Oficial de Cumplimiento, como por ejemplo en Colombia existe el SARLAFT, que es el conjunto de políticas y procedimientos que enmarcan el Sistema de Administración de Riesgos de Lavado de Activos, que no solo es el delito de lavado de dinero sino que implementa una gestión integral de riesgos de lavado de activos.

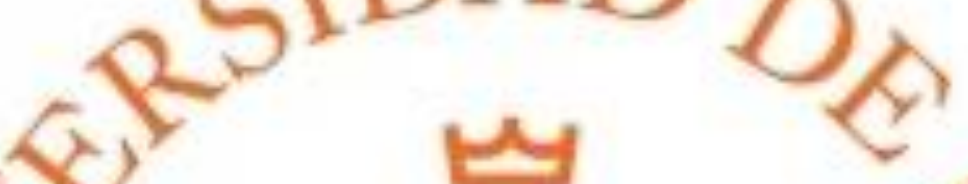

1.1.2.- Identificación del problema: por medio de preguntas a responder, estado de la cuestión, investigación preliminar, justificación/importancia.

\subsubsection{Identificación del problema}

Los Oficiales de Cumplimiento se ven expuestos de realizar sus labores, debido a que tienen una responsabilidad penal por fallas culposas externas a su gestión o por negligencia de otros funcionarios dentro de su institución, fallas en los sistemas o software, etc.

Como ejemplo se puede mencionar lo establecido en el artículo $29^{\circ}$ de la Res. SBS 2660-2015, la cual establece las etapas de la debida diligencia en el conocimiento del cliente, señalando como primera etapa la identificación de los clientes que se encuentra a cargo de los Funcionarios Comerciales del Banco quienes son los encargados de la captación de los clientes y por consiguiente deben conocer y saber quién es el cliente que traen a su institución, luego sigue la etapa de verificación y por último la etapa que le corresponde a las "líneas de defensa" dentro del Banco, que es la etapa de monitoreo, donde el Oficial de Cumplimiento es el encargado de vigilar al cliente que trajo el Funcionario Comercial.

Por tanto, si el Funcionario Comercial no realiza la debida diligencia antes del inicio de la relación comercial, traerá un cliente que perjudique al Banco, a menos que se 
detecte oportunamente las malas intenciones del cliente, de no ser así, el cliente lavará dinero hasta que sea detectado por el Oficial de Cumplimiento y si éste no lo detecta puede ser detectado por autoridades externas que finalmente responsabilizarán penalmente al Oficial de Cumplimiento por la negligencia de tener un cliente que lave dinero dentro de su institución.

\subsubsection{Preguntas a responder}

- ¿Afectaría a los Bancos eliminar la responsabilidad penal del Oficial de Cumplimiento?

- ¿Crecería el delito de lavado de activos si se elimina la responsabilidad penal?

- ¿El Oficial de Cumplimiento reduciría sus labores al eliminar su responsabilidad penal culposa?

- ¿Se podría implementar el concepto del Compliance Office en el Perú?

- ¿Pueden ser responsables penalmente los auditores internos y externos por los informes que emiten?

- ¿Los funcionarios comercial que traen y conocen a los clientes, deben ser incluidos en la norma penal del Oficial de Cumplimiento?

\subsubsection{Estado de la cuestión}

En la actualidad el artículo $5^{\circ}$, del Decreto Legislativo $\mathrm{N}^{\circ} 1106$ - Lucha eficaz contra el Lavado de Activos y otros delitos relacionados a la minería ilegal y crimen organizado, establece lo siguiente sobre el Oficial de Cumplimiento:

El que incumpliendo sus obligaciones funcionales o profesionales, omite comunicar a la autoridad competente, las transacciones u operaciones sospechosas que hubiere detectado, según las leyes y normas reglamentarias, será reprimido con pena privativa de la libertad no menor de cuatro ni mayor de ocho años, con ciento veinte a doscientos cincuenta días multa e inhabilitación no menor de cuatro ni mayor de seis años, de conformidad con los incisos 1), 2) y 4) del artículo $36^{\circ}$ del Código Penal. La omisión por culpa de la comunicación da 
transacciones u operaciones sospechosas será reprimida con pena de multa de ochenta a ciento cincuenta días multa e inhabilitación de uno a tres años, de conformidad con los incisos 1), 2) y 4) del artículo $36^{\circ}$ del Código Penal

Cabe indicar que en el Perú, no se han dado casos de prisión efectiva contra Oficiales de Cumplimiento del sistema financiero, sin embargo constantemente las instituciones financieras son multadas por no cumplir con las Políticas de Lavado de Activos de acuerdo a las normas locales e internacionales sobre la materia. No obstante a ello, en el mundo sí se han visto afectados Oficiales de Cumplimiento por de negligencia, como el que a continuación se comenta:

En enero de 2016 un Juez de la Corte de distrito de Estados Unidos en Minnesota indicó que los Oficiales de Cumplimiento pueden ser considerados legalmente responsables por fallas en los programas Lavado de Activos dentro de sus instituciones. La decisión del juez de la Corte Federal de Distrito, David Doty, fue contra el ex Director de Cumplimiento de la firma internacional de transmisión de dinero MoneyGram Thomas Haider, que está apelando una multa de US\$ 1 millón por presuntos errores que fue puesta en 2014 por la Red de Control de Crímenes Financieros del Departamento del Tesoro de Estados Unidos (FinCEN)

El fallo es definitivamente algo importante", dijo un Oficial de Cumplimiento de un gran banco con sede en Estados Unidos. "Es algo que da mucho miedo. Sienta un mal precedente para los profesionales de cumplimiento que realmente están tratando de hacer lo correcto. La mayoría de los Oficiales de Cumplimiento están haciendo las cosas bien y a conciencia". La medida contra Haider se produce en un momento muy particular en la historia del cumplimiento en materia de delitos financieros.

Brian Monroe, Enero 2016, Asociación de Especialistas Certificados en Delitos Financieros.

\subsubsection{Investigación preliminar}

Se realizará un análisis sobre el artículo de la norma en cuestión con base a la normativa nacional y extranjera relacionado al tema en investigación, la cual concluirá en demostrar 
la eficiente que sería el lograr la eliminación de la responsabilidad culposa para el Oficial de Cumplimiento, que resultará tener sistemas de prevención más sólidos para los Bancos.

Asimismo, se incluye el Acuerdo Plenario $N^{\circ}$ 7-2011/CJ-116 dictado el 06 de diciembre de 2011 que trata sobre el delito de Lavado de Activos y las medidas de coerción reales. Por el lado de la doctrina internacional se analizará Las Normas dictadas por el GAFI - Grupo de Acción Financiera Internacional.

Ley 27693, que definió las obligaciones de prevención, registro y reporte que debían cumplir los sectores vulnerables a operaciones de lavado de activos, constituyendo como autoridad supervisora de dichas obligaciones a la Unidad de Inteligencia Financiera del Perú, e instituyó un ente interno de apoyo al que denominó Oficial de Cumplimiento.

Ley 27765 o Ley Penal contra el Lavado de Activos, señalando la tipificación y represión de los delitos y entre los cuales se incluyó el delito de omisión de reporte de transacciones y operaciones sospechosas (artículo 4).

La responsabilidad civil del Oficial de Cumplimiento se presenta cuando el cliente reportado, por alguna circunstancia, deduce que la atribución que se le hace, de realizar prácticas de lavado de activos y que está causando perjuicio a la sociedad, ha sido originada en un eventual reporte efectuado por el Oficial de cumplimiento de un determinado sujeto obligado.

Bajo ese contexto, es que el cliente toma represarías contra el Oficial de Cumplimiento, iniciando contra él procesos penales por indemnización de daños o perjuicios y hasta en algunos casos atentando contra la vida del Oficial de Cumplimiento; es por ello que de acuerdo a la norma local, el nombre del Oficial de Cumplimiento se debe de mantener en absoluta reserva y confidencialidad por parte de todos los trabajadores de las instituciones financieras.

Por otro lado, se analizarán también los riesgos inherentes de los Bancos, en particular el riesgo de la investidura de la Oficialía de Cumplimiento, estrictamente a su responsabilidad penal, pero no me centraré en la responsabilidad penal por omisión a las operaciones sospechosas sino voy a ir más allá, es decir atacar directamente el Decreto Legislativo $\mathrm{N}^{\circ} 1106$ y modificar el artículo $5^{\circ}$ fundamentando mi posición en base a mi 
experiencia y a los casos suscitados en el gremio financiero, con la finalidad de incluir nuevos actores y mitigar riesgos para tener adecuados controles.

\subsubsection{Justificación/Importancia}

Será de vital importancia poder llegar a la conclusión de eliminar la responsabilidad penal culposa del Oficial de Cumplimiento en cuanto la relevancia del tema que significa para los funcionarios que se dedican a esa delicada labor.

Extinguir la responsabilidad penal en su forma culposa del Oficial de Cumplimiento ayudará a que éstos funcionarios desempeñen sus obligaciones con tranquilidad y puedan ser más eficientes, por lo que no podrán actuar por dudas o miedos legales a los que se encuentran expuestos.

Es por ello, que el Oficial de Cumplimiento al ser el responsable de vigilar el SPLAF implementado en los Bancos no sufrirá consecuencias legales por conductas ajenas a su labor que sean cometidas por terceros, en este caso por funcionarios que trabajan dentro de su misma institución o por fallas de los sistemas de información y software que ayudan a detectar operaciones inusuales o sospechosas.

Los riesgos individuales del Oficial de Cumplimiento se dan a consecuencia de la responsabilidad que genera su labor. Dicha responsabilidad podría dividirse entre aristas, dentro de las cuales tenemos:

- Responsabilidad administrativa/4 C M L X II

- Responsabilidad Civil

- Responsabilidad Penal

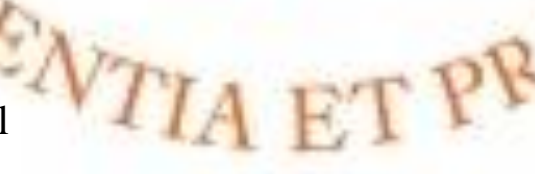

\subsection{Objetivos de la investigación: aportes de la investigación, objetivo central más objetivos específicos}




\subsubsection{Objetivos de la investigación}

Lograr eliminar la responsabilidad culposa del Oficial de Cumplimiento.

\subsubsection{Aportes de la investigación}

Dictar una norma consistente de acuerdo a las funciones del Oficial de Cumplimiento.

\subsubsection{Objetivo central más objetivos específicos}

El objetivo central es lograr eliminar la responsabilidad culposa del Oficial de Cumplimiento lo que resultará aplicar una norma más eficiente logrando que los Oficiales de Cumplimiento cumplan sus labores con mayor seguridad y respaldo.

Los objetivos específicos serían establecer un marco de respaldo y protección para los Oficiales de Cumplimiento en caso se vean expuestos a negligencias o actos de otros funcionarios.

Otro objetivo sería eliminar la responsabilidad del Oficial de Cumplimiento, en caso se compruebe que no reportó una operación sospechosa por falla de los sistemas o software que mantiene implementados en su institución.

Los objetivos aportarían a la prevención del delito, en cuanto a las medidas y acciones dispuestas a llevar a cabo con anticipación para evitar o impedir que se lave dinero dentro de los Bancos. Es decir, otorgarles seguridad jurídica a los Oficiales de Cumplimiento, resultaría que reporten operaciones sospechosas sin temor a ser denunciados o demandados. "La necesidad de promover y motivar una actitud decidida contra el lavado de activos entre los sectores vulnerables y sus operadores, ha generado también que en la legislación nacional sobre la materia, se hayan configurado para ellos, obligaciones y sanciones específicas que apuntan a consolidar su aporte diligente y proactivo a la prevención de esta clase delitos". (Victor Prado Saldarriaga, 2007, p.139) 


\subsection{Hipótesis de la investigación: Respuestas tentativas abiertas a verificación durante la investigación/descarte/confirmación}

Luego de haber formulado el problema citado en el artículo $5^{\circ}$ del Decreto Legislativo $\mathrm{N}^{\circ}$ 1106, la investigación se orientará a fundamentar la eliminación de la responsabilidad penal del Oficial de Cumplimiento para casos culposos y se buscará probar que no es necesario responsabilizar penalmente a los Oficiales de Cumplimiento para garantizar la prevención del lavado de activos, lo que llevaría que detecten y reporten operaciones sospechosas.

Por otro lado, para que el Oficial de Cumplimiento sea imputado por casos culposos debe concurrir el requisito previo a la acción, es decir la aptitud del Oficial de Cumplimiento de poder cometer el delito de lavado de activos y soportar su consecuencia. Para ello debe existir voluntad y potencial, para que se le atribuya tal conducta. Pues, condenarlo por hechos de terceros o fallas en los sistemas sería un hecho injusto y negativo que atentaría contra los derechos constitucionales de toda persona.

\subsection{Fuentes de investigación}

- Código Penal

- Decreto Legislativo No 1106 - Lucha eficaz contra el Lavado de Activos y otros delitos relacionados a la minería ilegal y crimen organizado.

- Res. SBS N² 2660-2015 que aprueba el Reglamento de Riesgos de Lavado de Activos y del Financiamiento del Terrorismo.

- Ley N 27693 "Ley que crea la Unidad de Inteligencia Financiera del Perú"

- Decreto Supremo N 018-2006-JUS que aprueba el Reglamento de la Ley que crea la Unidad de Inteligencia Financiera del Perú.

- La Ley contra el crimen organizado - Ley $\mathrm{N}^{\circ} 30077$ y su modificatoria mediante Ley $\mathrm{N}^{\circ} 30133$.

- El oficial de cumplimiento y sus funciones operativas, por Danilo Lugo C. 
- El Oficial de Cumplimiento (OC), autor: Cesar Terrones Linares.

- Caso de Oficiales de Cumplimiento en Paraguay

\subsection{Objeto específico}

Proveer de herramientas eficaces a los Oficiales de Cumplimiento para la prevención en el sistema del lavado de activos en el Perú.

El sistema de prevención de lavado de activos y de financiamiento del terrorismo tiene por finalidad permitir a los sujetos obligados gestionar sus riesgos de LA/FT, mediante la identificación, evaluación, control, mitigación y monitoreo a los riesgos de lavado de activos y del financiamiento del terrorismo que se encuentran expuestos. En ese sentido, el presente trabajo busca robustecer el sistema de prevención de lavado de activos de las instituciones financieras peruanas contribuyendo de esta manera a evitar que se vulneren y utilicen los productos y servicios bancarios para fines ilícitos. En ese orden de ideas, se presentarán herramientas que servirán de apoyo a los Oficiales de Cumplimiento de tal manera que blinden su trabajo y lo efectúen sin temores a represarías civiles, penales y administrativas.

La gestión de riesgos de LA/FT debe comprender, entre otros procedimientos y controles eficaces para proveer a los Oficiales de Cumplimiento, seguridad jurídica en la elaboración y presentación de sus reportes de operaciones inusuales y sospechosas.

Unas de las principales funciones del Oficial de Cumplimiento consiste en calificar a una operación inusual comó sospechosa y comunicarla a la UIF-Perú a través del Reporte de Operación Sospechosa y dentro del plazo que establece la Ley. No reportar una operación calificada como sospechosa por parte del Oficial de Cumplimiento, trae como consecuencia que éste quede incurso en la comisión del delito de omisión de comunicación de operaciones o transacciones sospechosas, previsto y sancionado por el artículo $5^{\circ}$ del Decreto Legislativo 1106, Ley Penal contra el Lavado de Activos.

La necesidad de promover y motivar una actitud decidida contra el lavado de activos entre los sectores vulnerables y sus operadores, ha generado también que en la legislación nacional sobre la materia, se hayan configurado para ellos, obligaciones y sanciones 
específicas que apuntan a consolidar su aporte diligente y proactivo a la prevención de esta clase delitos. (Prado Saldarriaga, 1991, párr. 6)

En consecuencia a lo antes descrito, es importante implementar herramientas eficaces con el objetivo de fortalecer el sistema de prevención de lavado de activos con lo que se lograría que los Oficiales de Cumplimiento puedan ejercer sus funciones con seguridad y no se perjudiquen ante eventos de terceros o funcionarios negligentes que causen perjuicio al cargo del Oficial de Cumplimiento de una institución financiera.

Es necesario modificar la norma que responsabiliza penalmente al Oficial de Cumplimiento, en el sentido, no de eximirlo de responsabilidad, al contrario, se deben dejar claros los supuestos en que el Oficial de Cumplimiento debe ser responsable penalmente desde la perspectiva del dolo e incluir a los Funcionarios Bancarios que mantiene contacto de directo con los clientes para que asuman sus funciones y provean de herramientas eficaces a los Oficiales de Cumplimiento para que éstos puedan cumplir sin miedos o temores sus funciones y de esa manera se fortalecerán los sistema de prevención de lavado de activos y del financiamiento del terrorismo de las instituciones financieras en el Perú, lo cual también traerá resultado favorables que ayudarán a reducir los índices de criminalidad e inseguridad que en la actualidad se presencia en nuestro país.

Finalmente, este trabajo busca proponer herramientas eficaces, con la finalidad que los Oficiales de Cumplimiento cumplan con implementar un sistema sólido de prevención de lavado de activos en el Perú. Es por ello, que se propone modificar la parte normativa local, que responsabiliza penalmente al Oficial de Cumplimiento por actos de omisión de reportes de operaciones sospechosas, estableciendo requisitos específicos de responsabilidad penal; lo que resultaría en mejorar la calidad de los reportes de operaciones sospechosas y con ello se lograría fortalecer el sistema de prevención de lavado de activos de los sujetos obligados, pues otorgaría seguridad a los Oficiales de Cumplimiento en el ejercicios de sus funciones y originaría que el rol del Oficial de Cumplimiento sea relevante dentro de las instituciones, al igual por ejemplo del rol que cumple el Auditor Interno, pues ambos comparten las obligaciones como órgano de control interno pero no tienen la misma relevancia dentro de las instituciones financieras peruanas en la actualidad. 


\subsection{Contenido}

\subsection{1. ¿Qué es el lavado de activos?}

El delito de lavado de activos es la forma de ocultar o disimular el origen del dinero, y/o bienes, propiedades obtenidos ilegalmente. Asimismo, el lavado de activos consiste en introducir en el sistema financiero activos de procedencia ilícita con el fin de darles la apariencia de legalidad a lo originada ilegalmente, lo que permite a delincuentes y organizaciones criminales blanquear o lavar el origen ilegal de su producto sin poner al descubierto su fuente.

El lavado de activos tiene al narcotráfico como el principal delito base, sin embargo existen delitos precedentes, los cuales son los siguientes: venta ilegal de armas, la trata de personas, las redes de prostitución, la malversación de fondos públicos, el uso malicioso de información privilegiada, el cohecho, el fraude informático y el terrorismo, estafa, corrupción, minería ilegal, delitos contra los derechos de autor, secuestro, entre otros delitos. Todos los delitos descritos producen y originan dinero ilegal por lo que los delincuentes buscan disfrazar el origen ilícito del dinero.

Es muy importante tener en cuenta los delitos precedentes pues se cree y se confunde que el lavado de activos solo proviene del narcotráfico cuando en realidad no es así, de acuerdo a estadísticas de la Unidad de Inteligencia Financiera, los delitos de corrupción y minería ilegal han presentado mayor número de reportes de operaciones sospechosas, así también tenemos que delitos como el de evasión y defraudación tributaria han presentado incrementos en cuanto a reportes de operaciones sospechosas por parte de los Sujetos Obligados.

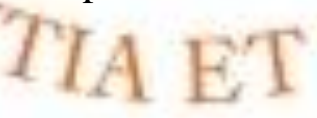

Otras formas de delincuencia que están mostrando un crecimiento como fuente del lavado de activos las encontramos en el sector inmobiliario, pues existen muchos proyectos que presentan constructoras y no pueden justificar fehacientemente el origen de los fondos para adquirir las casas o terrenos donde construirán el edificio y ligado a esto tenemos nuevas tipologías como por ejemplo la cuota inicial que dan las personas a las 
constructoras para comprar un inmueble, pues estos pagos iniciales van siempre directo a las arcas del constructor y no pasan a través de los Bancos.

Pinilla (2003) define el lavado de activos como:

La omisión de control, el testaferrato y el enriquecimiento ilícito de particulares, son delitos contra la licitud en la procedencia, la adquisición, la titularización y el aprovechamiento de bienes, las conductas cometidas para ocultar, asegurar, adquirir o expender el producto de actividades ilícitas, antiguamente podían hallar configuración penal únicamente bajo las previsiones tradicionales de un delito de administración de justicia, la receptación. (p. 03)

Entre los principales riesgos inmersos en los delitos precedentes de lavado de activos y financiamiento del terrorismo se destacan los siguientes:

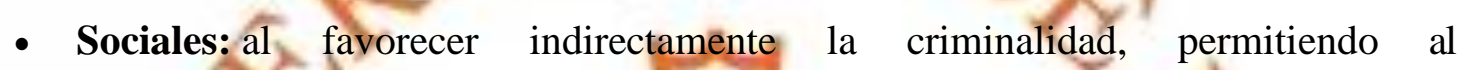
delincuénte legitimar el producto del delito.

- Económicos: al producir distorsiones en los movimientos financieros e inflar industrias o sectores más vulnerables.

- Financieros: al introducir desequilibrios macroeconómicos y dañar la integridad del sistema financiero.

- Reputacionales: por la pérdida de prestigio, crédito y/o reputación tanto de entidades financieras como no financieras y de sus profesionales.

- Legales: causan perjuicios demandas y denuncias contra las instituciones y sus funcionarios.

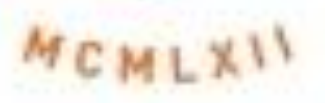

En ese orden de ideas, el delito de lavado de activos es muy nefasto no solo para las empresas sino que su implicancia daña a todo un ordenamiento jurídico y estatal, por ello la importancia de combatirlo y reprimirlo pues las consecuencias de lavar dinero son perjudiciales para el sector privado y sector público.

Por otro lado, considero que en la actualidad el delito de lavado de activos se está "contaminando", es decir cualquier delito que cometa una persona ahora le abren una investigación por lavado de activos, cuando en realidad el delito fuente puede ser otro, como por ejemplo: asociación ilícita para delinquir, estafa, defraudación tributaria, etc. 
En ese sentido, se tiene que delimitar de manera correcta el delito fuente pues no todo se puede enmarcar en lavado de activos, pues si bien el lavado de activos proviene de actividades ilícitas no podemos enfrentar una estafa vs. Lavado de activos, pues si el fin del autor del delito fue engañar a su víctima mediante astucia para aprovechar de él entonces en ese caso se está configurando el delito de estafa como delito fuente.

Sin embargo puede existir la concurrencia de delios, en el caso que producto de una extorsión se obtiene una cantidad de dinero y este dinero se ingresa al sistema financiero para darle legalidad, ahí existirían los delitos de extorsión como delito fuente y lavado de activos como consecuencia de la actividad ilícita que originó el dinero mal habido.

Asimismo, es importante hacer mención a los riesgos que afrontan las empresas cuando se ven frente a delitos precedentes de lavado de activos, pues de ocurrir un hecho delictivo dentro de una institución privada, no sólo ésta puede ser sancionada con multa sino que también puede conllevar a abarcar sanciones reputacionales que en muchos casos son más severas que pagar multas pecuniarias, debido a que en el caso de los Bancos, la imagen y confianza que transmiten a sus clientes es de vital importancia para el negocio, y de debilitarse tal credibilidad se verían afectados con el retiro masivo de clientes lo que ocasionaría la quiebra por fondos de la institución financiera.

Un riesgo importante y que no se ha mencionado entre los principales riesgos descritos, es el "riesgo operacional" que se debe a falla en los sistemas. Los Oficiales de Cumplimiento para ejecutar sus labores se apoyan en software o herramientas tecnológicas que sirven de base para monitorear transacciones y determinan la inusualidad de las operaciones de acuerdo al perfil de los clientes, sin embargo si fallan las herramientas tecnológicas, existe la posibilidad de que se realicen operaciones inusuales dentro de una institución y que el Oficial de Cumplimiento no las detecté porque su sistema falló, en ese caso la norma (Artc. $5^{\circ}$ DL 1106) deja una mala interpretación abierta, debido a que se le puede acusar de negligente al Oficial de Cumplimiento por una falla en su sistema, lo cual sería nefasto para las labores de los Oficiales de Cumplimiento, ya que los sistemas no son infalible y siempre existe la posibilidad de que fallen, es por ello que toda institución financiera asume riesgos desde que abre una oficina o agencia bancaria, puesto que siempre estaría latente la posibilidad de que sufra algún robo a asalto dentro de la agencia, sin 
embargo el riesgo operacional no puede ser imputado directamente al Oficial de Cumplimiento y por consiguiente aplicar la modificación sugerida al Art. $5^{\circ}$ del DL 1106, aclararía y definiría este punto mencionado y otros más que a lo largo del trabajo iré analizando.

\subsubsection{Etapas del lavado de activos}

Introducción - Colocación: El dinero se convierte en instrumentos monetarios o se deposita en las cuentas de instituciones financieras. Los delincuentes mediante artimañas buscan ingresar dinero de origen ilícito al sistema financiero, pese a que los Bancos cuentan con políticas preventivas de conocimiento del cliente y con software de alertas de lavado de activos que ayudan a mitigar los riesgos, los delincuentes actualizan sus alternativas de burlar esas vallas preventivas.

Asimismo, existen tipologías que usan los delincuentes en la actualidad, la mismas que son conocidas por todos, por tanto las personas que pretender introducir dinero ilícito en las instituciones financieras, constantemente innovan sus formas de delinquir y también existen bandas de organizăciones criminales que invierten dinero en software y herramientas tecnológica con la finalidad de burlas las defensas de los Bancos.

Transformación - Diversificación: Los fondos son trasladados hacia otras instituciones financieras para esconder sus orígenes. Es decir, una vez ingresado el dinero ilícito a la institución financiera, los delincuentes buscan acceder a los productos y servicios bancarios con la finalidad de diversificar el dinero ilícito y darle la apariencia legal, solicitando préstamos, adquiriendo tarjetas de crédito, etc.

En la etapa de Transformación los delincuentes usan testaferros en la mayoría de los casos o utilizan personas solo para fines específicos, como por ejemplo para solicitar un determinado producto activo con el objetivo que el Banco realice el desembolso y luego de ello, se cancela el producto con dinero ilícito dándole legalidad al dinero o bien mueble o inmueble adquirido.

Integración - Reingreso: Los fondos son utilizados para adquirir activos legítimos o financiar otras actividades, es decir el dinero se encuentra "blanqueado" pues le dieron una 
apariencia legal y se concentran en sacarlo del sistema financiero para financiar sus actividades ilícitas. Esta es la etapa final donde los delincuentes lograron su cometido y pudieron lavar dinero ilícito por tanto es fácil para ellos inserta el dinero en actividades comerciales o empresas fachadas creadas con el fin específico de lavar la cantidad de dinero posible hasta que sean descubiertos.

A continuación se muestra un gráfico que describe los pasos que utilizan los delincuentes para lavar dinero:

Figura 1.1.

Los pasos del lavado de activos
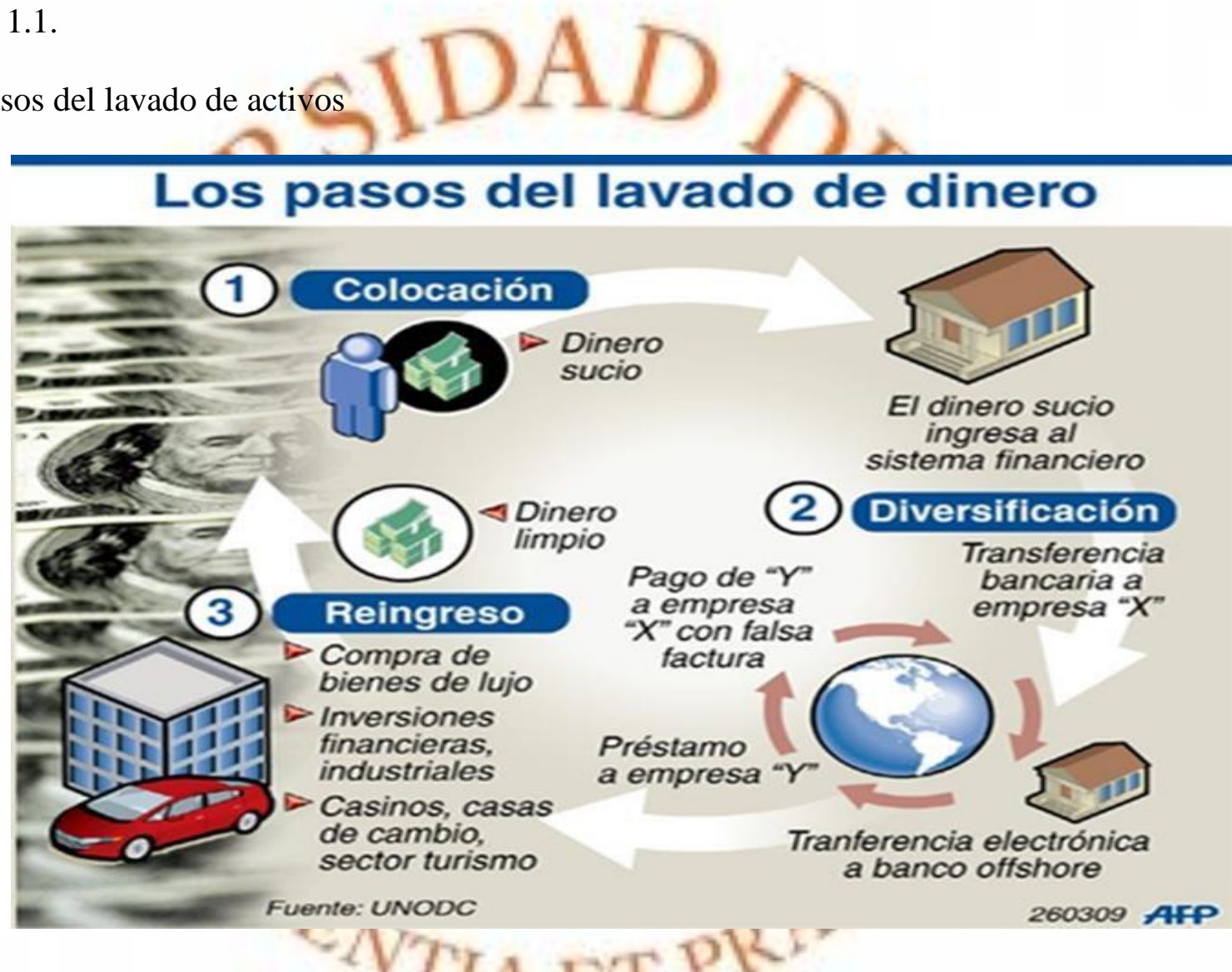

Fuente: UNODC (Oficina de las Naciones Unidad contra la droga y el delito)

\subsubsection{Factores de riesgo de lavado de activos}

Un factor de riesgo es toda circunstancia o situación que aumenta las probabilidades de una persona natural o jurídica de contraer un problema. Los factores de riesgo implican que las personas afectadas por dicho factor de riesgo, presentan un riesgo mayor al de las personas sin este factor. 
Los factores de riesgo están presentes de manera preponderante dentro del Sistema de Administración del Riesgo de Lavado de Activos y Financiación del Terrorismo (SARLAFT) y, dichos factores de riesgo son los agentes generadores del riesgo de LA/FT. Siempre van a existir factores de riesgos, en todas las especialidades y materias, no obstante a ello, el rol principal de los sistemas de prevención es detectar los factores de riesgos y aplicar controles con el fin de evitar los riesgos inmersos descritos.

Los factores aparecen dentro de la etapa de identificación como objeto de una segmentación; es decir dentro de la etapa de medición como objeto de valoración de posibilidad o probabilidad de ocurrencia del riesgo; dentro de la etapa de control como objeto de los controles; y dentro de la etapa de monitoreo como objeto para la comparación entre el riesgo inherente y el residual.

Es por ello que, el riesgo inherente es el riesgo con el que nace la empresa, es un riesgo que no puede ser eliminado porque se trata de la misma actividad en particular; y el riesgo residual es aquel que permanece después de haber implementado controles.

Riesgo: Es la amenaza de que un evento o acción afecte adversamente la habilidad de una organización de lograr sus objetivos de negocios o ejecutar sus estrategias exitosamente. Administración del Riesgo: Proceso mediante el cual la dirección de una empresa identifica, identifica, cuantifica y controla los riesgos a los cuales la exponen sus actividades. (Castro, 2009, p.73)

Cabe destacar que cada uno de los factores de riesgo debe contar con señales de alerta propias. Para el caso del factor "canal" (cajeros automáticos, banco por internet, etc.) por ejemplo es ideal que las señales de alerta tengan en cuenta todas las modalidades que la entidad haya adoptado.

Es importante indicar que los factores de riesgos se implementan de acuerdo a la realidad de las instituciones financieras, pues dependerá del sector económico en que se encuentren segmentados sus clientes, el ofrecimiento de sus productos y servicios en los distintos mercados, los canales de distribución de los productos, las zonas geográficas donde tienen mayor influencia y los aspectos transaccionales de sus clientes, es por ello que todos estos factores debidamente mapeados ayudan a mitigar riesgos luego de haberse 
implementando un sistema sólido de prevención de riesgos de lavado de activos y de financiamiento del terrorismo.

En el año 2015 la Superintendencia de Banca, Seguros y AFP, mediante la Resolución $\mathrm{N}^{\circ}$ 2660-2015, emitió una nueva norma enfocada principalmente a gestionar los riesgos de lavado de activos y financiamiento del terrorismo de todos los Sujetos Obligados. La norma citada trae conceptos nuevos para el sistema financiero peruano, sin embargo en países como Colombia por ejemplo, el enfoque basado en riesgos existe aproximadamente hace ocho años.

En consecuencia a ello, las entidades financieras hoy en día, han implementado metodologías para mitigar los riesgos de lavado de activos, no obstante a ello, cada metodología implementada va acorde con las políticas y procedimientos de las empresas, es decir va acorde con la realidad de los Bancos.

En ese orden de ideas, a partir del 2015 el sistema financiero y en general todos los Sujetos Obligados han experimentados cambios que ayudan a mejor sùs Sistemas de Prevención de Lavado de Activos, pues una de las novedades de la normas es que se realice el perfilamiento individual de clientes, por tanto cada cliente de una institución financiera posee un score o calificación de riesgos de lavado de activos, similar al score crediticio, y si un cliente mantiene un score de riesgos de lavado de activos muy alto, debe ser desvinculado de la institución y hasta reportado a la Unidad de Inteligencia Financiera.

Cabe mencionar, la nueva norma que entro en vigencia en el año 2015 ha sido de gran apoyo para los sistemas de prevención de lavado de activos, pues ayuda tener mapeados e identificados a los clientes riesgos para el lavado de activos y en base a ello, se realizan procesos de debida diligencia y control para vigilar las operaciones que realizan, de tal manera que puedan ser reportados a la Unidad de Inteligencia Financiera.

En consecuencia a ello, si una persona se quiere vincular a una institución financiera, ésta le realizará una serie de preguntas para determinar un resultado o score de riesgos de lavado de activos, en caso la persona presente un score elevado o altamente riesgoso no podría ser vinculado al Banco y en caso lo vinculen, sobre él pesarán monitores reforzados para detectar sus operaciones inusuales, en caso las pretenda realizar. 
Por otro lado, si una persona que solicita vincular al Banco y la institución financiera le realice una serie de preguntas para determinar el grado el grado de riesgos de lavado de activos y ésta persona engaña al Banco con sus respuestas y finalmente logra vincularse con un score de riesgos de lavado de activos muy bajo, el Banco periódicamente tiene la obligación de revisar la transaccionalidad del cliente y de la revisión se evidenciarán las operaciones inusuales que realice el cliente, lo que ocasionará el cambio de score de riesgos de lavado de activos con el que se vinculó inicialmente.

\subsection{Marco Nacional e Internacional del lavado de activos}

Así como en todos los ámbitos regulados, en el campo del lavado de activos, los Sujetos Obligados se encuentran normados por reguladores nacionales e internacionales; en ese sentido, en el ámbito nacional el principal regulador en el sistema financiero es la Superintendencia de Banca, Seguros y AFPs, además existen otros entes reguladores. En el ámbito internacional, no son reguladores propiamente dichos, pero son organismos creados para ayudar implementar recomendaciones dada su experiencia y expertise, como lo son el Grupo de Acción Financiera - GAFI, el Organismo Internacional de Naciones Unidas, los acuerdos de Basilea, FATCA y sus normas, entre otros.

Es importante indicar que los organismos internacionales no tienen injerencia sobre los sujetos obligados peruanos pero si no cumplimos con sus recomendaciones estaríamos evadiendo una buena aplicación a nuestros sistemas de prevención, lo que conllevaría a que nuestros corresponsables no trabajen con nosotros, nuestras operaciones internacionales no sean procesadas, entre otros castigos que al final son sanciones más severas que una multa impuesta por un regulador peruano.

Por ejemplo debo mencionar el caso de la Ley de Cumplimiento Fiscal de Cuentas Extranjeras (FATCA por sus iniciales en inglés), que tiene como objetivo evitar que los ciudadanos norteamericanos evadan impuestos, sin embargo esa norma americana no tiene ningún fundamento legal para que sea aplicada en el Perú, debido a que no tenemos ningún Convenio firmado entre estados (Perú y USA) para que esa ley se pueda aplicar en nuestro más, más aún cuando ese dispositivo legal obliga a todos los Bancos a divulgar al IRS de Estados Unidos (al fisco) todos los saldos pasivos de los clientes norteamericanos, pues en 
el Perú prima el derecho constitucional denominado secreto bancario ${ }^{1}$, que blinda a todos los clientes de los Bancos a no divulgar la información sobre sus cuentas e información bancaria. Asimismo, la Ley N $N^{\circ} 6702$ - Ley General del Sistema Financiero ${ }^{2}$, establece el alcance de la prohibición sobre suministrar cualquier información de las operaciones pasivas de los clientes a menos que medie una autorización escrita de los clientes o que ésta sea solicitada por un juez, Fiscal de la Nación, una comisión investigadora del Congreso de la República, el Superintendente de la SBS o el gobierno de un país con el que se tenga un Convenio suscrito para combatir, reprimir y sancionar el tráfico ilícito de drogas o el terrorismo.

El sistema de prevención de lavado de activos contempla un conjunto de normas, criterios, metodologías y lineamientos que sirven para implementar la prevención de lavado de activos y el financiamiento del terrorismo en las instituciones de los sujetos obligados

${ }^{1}$ Constitución Política del Perú

Artículo $2^{\circ}$.- Toda persona tiene derecho:

5. A solicitar sin expresión de causa la información que requiera y a recibirla de cualquier entidad pública, en el plazo legal, con el costo que suponga el pedido. Se exceptúan las informaciones que afectan la intimidad personal y las que expresamente se excluyan por ley o por razones de seguridad nacional. El secreto bancario y la reserva tributaria pueden levantarse a pedido del juez, del Fiscal de la Nación, o de una comisión investigadora del Congreso con arreglo a ley y siempre que se refieran al caso investigado.

${ }^{2}$ Ley N ${ }^{\circ} 26702$ - Ley General del Sistema Financiero

Secreto Bancario

Artículo 140.- ALCANCE DE LA PROHIBICION.

Está prohibido a las empresas del sistema financiero, así como a sus directores y trabajadores, suministrar cualquier información sobre las operaciones pasivas con sus clientes, a menos que medie autorización escrita de éstos o se trate de los supuestos consignados en los Artículos 142 y 143.

También se encuentran obligados a observar el secreto bancario:

1. El Superintendente y los trabajadores de la Superintendencia, salvo que se trate de la información respecto a los titulares de cuentas corrientes cerradas por el giro de cheques sin provisión de fondos.

2. Los directores y trabajadores del Banco Central de Reserva del Perú.

3. Los directores y trabajadores de las sociedades de auditoría y de las empresas clasificadoras de riesgo. No rige esta norma tratándose de los movimientos sôspechosos de lavado de dinero o de activos, a que se refiere la Sección Quinta de esta Ley, en cuyo caso la empresa está obligada a comunicar acerca de tales movimientos a la Unidad de Inteligencia Financiera.

No incurren en responsabilidad legal, la empresa y/o sus trabajadores que, en cumplimento de la obligación contenida en el presente artículo, hagan de conocimiento de la Unidad de Inteligencia Financiera, movimientos o transacciones sospechosas que, por su naturaleza, puedan ocultar operaciones de lavado de dinero o de activos. La autoridad correspondiente inicia las investigaciones necesarias y, en ningún caso, dicha comunicación puede ser fundamento para la interposición de acciones civiles, penales e indemnizatorias contra la empresa y/o sus funcionarios.

Tampoco incurren en responsabilidad quienes se abstengan de proporcionar información sujeta al secreto bancario a personas distintas a las referidas en el Artículo 143. Las autoridades que persistan en requerirla quedan incursas en el delito de abuso de autoridad tipificado en el Artículo 376 del Código Penal." 
(instituciones financieras, casas de cambio, notarias, mineras, cooperativas, etc). Entre las normas más importantes tenemos:

\subsection{Normas internas y externas}

Las normas nacionales para el sistema de prevención de lavado de activos y el financiamiento del terrorismo, son:

- Ley General del Sistema Financiero y del Sistema de Seguros y Orgánica de la SBS, Ley No 26702.

- Ley No 27693, Ley que crea la Unidad de Inteligencia Financiera del Perú y sus modificatorias.

- Ley $\mathrm{N}^{\circ}$ 27765, Ley Penal contra el Lavado de Activos y sus modificatorias.

- Ley № 29038, Ley que incorpora la Unidad de Inteligencia Financiera a la SBS.

- Decreto Ley No 25475 Ley que establece la penalidad para los delitos de terrorismo y los procedimientos para la investigación, la instrucción y el juicio.

- Decreto Supremo No 018-2006-JUS, Reglamento de la Ley que crea la Unidad de Inteligencia Financiera.

- Resoluciōn SBS N²660-2015 Reglamento de Gestión de Riesgos de Lavado de Activos y del Financiamiento del Terrorismo.

Las normas internacionales para el sistéma de prevención de lavado de activos y el financiamiento del terrorismo, son:

- Normas internacionales contra el blanqueo de capitales, financiamiento del terrorismo y la proliferación - Recomendaciones del Grupo de Acción Financiera (GAFI).

- Declaración de Principios de Basilea sobre prevención de la utilización del sistema bancario para blanquear fondos de origen criminal del Comité sobre Regulación y Supervisión Bancaria. 
- Convención europea sobre blanqueo, seguimiento, secuestro y decomiso del producto del crimen.

- Convenio Centroamericano para la prevención y represión de los delitos de Lavado de dinero y activos, relacionados con el tráfico ilícito de drogas y delitos conexos.

- Reglamento modelo de la Comisión Interamericana para el Control del Abuso de Drogas (CICAD)- Organización de los Estados Americanos (OEA).

\subsection{Impacto Normativo}

Descrito el punto 3.1 sobre las normas locales e internacionales de prevención de lavado de activos y el financiamiento del terrorismo, a continuación se presenta el artículo $5^{\circ}$ del Decreto Legislativo No 1106 que aprueba "La lucha eficaz contra el lavado de activos y otros delitos relacionados a la minería ilegal y crimen organizado”.

Artículo que se pondrá en discusión en el presente trabajo y que a mi parecer, es de vital importancia su modificación para proveer una herramienta legal segura para los Oficiales de Cumplimiento con el objetivo de fortalecer el sistema de prevención de lavado de activos para las instituciones financieras donde laboran.

Artículo $5^{\circ}$.- Omisión de comunicación de operaciones o transacciones sospechosas

El que incumpliendo sus obligaciones funcionales o profesionales, omite comunicar a la autoridad competente, las transacciones u operaciones sospechosas que hubiere detectado, según las leyes y normas reglamentarias, será reprimido con pena privativa de la libertad no menor de cuatro ni mayor de ocho años, con ciento veinte a doscientos cincuenta días multa e inhabilitación no menor de cuatro ni mayor de seis años, de conformidad con los incisos 1), 2) y 4) del artículo $36^{\circ}$ del Código Penal ${ }^{3}$.

\footnotetext{
$\overline{{ }^{3} \text { incisos 1), 2) y 4) del artículo } 36^{\circ}}$ del Código Penal. Artículo 36. Inhabilitación

La inhabilitación produce, según disponga la sentencia:

1) Privación de la función, cargo o comisión que ejercía el condenado, aunque provenga de elección popular;

2) Incapacidad o impedimento para obtener mandato, cargo, empleo o comisión de carácter público;

4) Incapacidad para ejercer por cuenta propia o por intermedio de tercero profesión, comercio, arte o industria, que deben especificarse en la sentencia;
} 
"La omisión por culpa de la comunicación de transacciones u operaciones sospechosas serán reprimidas con pena de multa de ochenta a ciento cincuenta días multa e inhabilitación de uno a tres años, de conformidad con los incisos 1), 2) y 4) del artículo $36^{\circ}$ del Código Penal.

En consecuencia a lo antes descrito, la modificación del mencionado artículo conllevaría a un cambio importante para los sistemas de prevención de lavado de activos para las instituciones del sistema nacional pues otorgaría seguridad en las labores de los Oficiales de Cumplimiento lo cual arrojaría que realicen sus labores con mayor eficiencia y reporten operaciones sospechosas sin temor a represarías.

La modificación tendría un impacto positivo debido a que se busca establecer requisitos y delimitar los casos dolosos y culposos en cuanto a las funciones del Oficial de Cumplimiento y además se pretende introducir en el marco normativo a los demás funcionarios que participan en la generación de reportes de operaciones sospechosas con la finalidad de implementar un sistema de lavado de activos más consistente, donde todos los involucrados sean partícipes de cumplir con las normas de lavado y de esa manera evitar que los productos y servicios que brindan las instituciones financieras sean utilizados para fines ilícitos.

En la actualidad existen muchas interpretaciones sobre este artículo principalmente si constituye el delito el no reportar una operación sospechosa, en ese sentido para que no existan falsas interpretaciones que intimidan la labor de los Oficiales de Cumplimiento, es de suma importancia modificar el artículo y dejar claro que el no reportar no constituye un delito pues la calificación de una operación sospechosa queda al "buen criterio" del Oficial de Cumplimiento, tal y como lo señala la Res. SBS 2660-2015, sin embargo al día de hoy un fiscal puede citar a un Oficial de Cumplimiento para que le "aclare" ciertas dudas relacionadas a una investigación que estaría llevando, por lo que, de concurrir un Oficial de Cumplimiento a prestar su manifestación sobre una investigación de lavado de activos, se estarían vulnerando la confidencialidad de su nombre y también la reserva de información que contiene un Reporte de Operación Sospechosa”.

\subsection{Propuesta normativa}


Luego de haber analizado el impacto normativo, por los argumentos expuestos se propone modificar el artículo $5^{\circ}$ del Decreto Legislativo $\mathrm{N}^{\circ} 1106$ que aprueba "La lucha eficaz contra el lavado de activos y otros delitos relacionados a la minería ilegal y crimen organizado".

En tal sentido, la propuesta normativa sería la siguiente:

\section{Artículo 5 $5^{\circ}$ - Omisión de comunicación de operaciones o transacciones sospechosas}

El que incumpliendo sus obligaciones funcionales como sujeto obligado, omite comunicar a la autoridad competente, las transacciones u operaciones sospechosas que hubiere detectado correspondientes al delito de lavado de activos, según las leyes y normas reglamentarias, será reprimido con pena privativa de la libertad no menor de cuatro ni mayor de ocho años, con ciento veinte a doscientos cincuenta días multa e inhabilitación no menor de cuatro ni mayor de seis años, de conformidad con los incisos 1), 2) y 4) del artículo $36^{\circ}$ del Código Penal.

En caso se presente la omisión por culpa por parte de un sujeto obligado en una operación o transacción sospechosa, dicha conducta será reprimida con pena de multa de ochenta a ciento cincuenta días multa e inhabilitación de uno a tres años, de conformidad con los incisos 1), 2) y 4) del artículo $36^{\circ}$ del Código Penal.

Si por culpa de un tercero el sujeto obligado omite comunicar una transacción u operación sospechosa, el tercero será reprimido con pena privativa de libertad ni menor de dos ni mayor de cuatro años y con ciento veinte a ciento ochenta días-multa.

La modificación propuesta elimina la responsabilidad por culpa del Oficial de Cumplimiento y aclara que su participación en actos dolosos con intensión si deberían ser castigados con pena privativa de la libertad. Asimismo, se agrega en el segundo párrafo la participación de terceros, que para estos casos, son los Funcionarios bancarios que se encuentran a cargo de las cuentas de los clientes, pues estos Funcionarios son los que realmente conocen al cliente, pues ellos los traen al banco, los vinculan, les ofrecen los productos y servicios que brinda la institución financiera y acompañan en el día a día al cliente, por tal motivo la política bancaria de "Conoce a tu Cliente" siempre recae sobre los Funcionarios que mantienen trato directo con los clientes. 
En sentido, se busca incluir al personal que labora en los Bancos sobre la importancia de prevenir el Lavado de Activos y el Financiamiento del Terrorismo a través del cumplimiento de los procedimientos y la utilización de las herramientas definidas, el incumplimiento de las mismas, resultaría que también se encuentren involucrados en las responsabilidades penales descritas en la propuesta del artículo modificado.

Cabe mencionar, que la designación de un Oficial de Cumplimiento en el sistema financiero la realiza el máximo órgano de una institución, que es el Directorio, órgano colegiado que toma las principales decisiones de una organización, luego de ello la designación con el nombre del Oficial de Cumplimiento es puesta a conocimiento y aprobación de la Superintendencia de Banca, Seguros y AFP, institución reguladora de todos los Bancos, la cual realiza un examen específico donde analiza los requisitos que debe cumplir la persona designada por el Directorio.

La SBS solicita internamente la opinión de varias de sus Intendencias (Riesgos, Legal, UIF, etc), donde cada Intendencia evalúa y da su opinión sobre el Curriculum y otros requisitos que debe cumplir el Oficial de Cumplimiento designado, si todas las Intendencias opinan favorablemente, es que la SBS aprueba la designación del Oficial de Cumplimiento.

En ese sentido, de acuerdo a lo comentado, partimos de la premisa que el Oficial de Cumplimiento de una institución financiera es una persona capaz, honesta, capacitado profesionalmente para cumplir con las labores que le han designado y* por ende es incongruente pretender involucrarlo ante eventos culposos o negligentes de lavado de activos que se puedan presentar en su institución, sin embargo en la actualidad el artículo $5^{\circ}$ en discusión, deja la posibilidad de involucrar a un Oficial de Cumplimiento en procesos penales por el hecho de no comunicar una operación sospechosa.

En consecuencia a ello, comprometer a terceros funcionarios o terceras personas como por ejemplo sociedades auditoras externas u otra persona o ente encargada de velar por el cumplimiento de las políticas de los Sistemas de Prevención de Lavado de Activos, deben ser involucradas en la modificación del Artículo $5^{\circ}$, pues la labor de estos terceros es importante para la mitigación de riesgos. 
En ese sentido, la modificación también trae consigo implementar una sanción con pena privativa de la libertad, sanción pecuniaria e inhabilitación por tres años, dado que no se debe limitar a castigar la culpa o negligencia con un simple multa como lo castiga en la actualidad el artículo $5^{\circ}$ en discusión.

Considero importante involucrar en las labores de prevención de lavado de activos a todos los terceros que se encuentran inmersos en las labores del Oficial de Cumplimiento, como lo son las personas siguientes:

- Funcionarios de Negocios o Comerciales: Este tipo de funcionario bancario son los que conocen al cliente, pues ellos son los que presentan al Banco al cliente, lo vinculan y lo acompañan durante toda la relación comercial que mantiene en el Banco.

Cuando se presenta una operación inusual, el Oficial de Cumplimiento solicita apoyo al Funcionario Comercial para que le explique el fundamento legal de la operación pues es el Funcionario Comercial quien conoce al cliente.

En caso, el Funcionario Comercial sea cómplice del cliente que se encuentre lavando dinero dentro del Banco, entonces le proporcionará información errónea, manipulada o falsa al Oficial de Cumplimiento, para que éste no califique como sospechosa la operación inusual presentada.

s

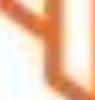

- Sociedades de Auditorías externas: Los Sistemas de Prevención de Lavado de Activos, por Res. SBS N ${ }^{\circ}$ 17026-2010 - Reglamento de Auditoría Externa, están obligados a ser evaluados una vez al año por la sociedad auditora externa que la Junta de Accionistas, o en su defecto el Directorio designe.

En ese sentido, es importante la labor que desempeñan los auditores externos, pues de acuerdo a la revisión que realicen encontrarán observaciones o recomendaciones que el Oficial de Cumplimiento deberá corregir para fortalecer el sistema de prevención de lavado de activos dentro de su institución, es por ello que si no existe una verdadera supervisión externa, el Oficial de Cumplimiento 
creerá que su sistema funciona bien, lo que puede ser un error pues puede presentarse un caso de lavado de activos que desacredite su sistema de prevención.

- Auditores Internos: El auditor interno como órgano de control interno debe conocer fehacientemente las funciones y obligaciones del Oficial de Cumplimiento con el objetivo de poder supervisar sus funciones.

Las auditorías no deben ceñirse a cumplir con un check list, el cual solo tiene el número de políticas y procesos que tiene el ảrea de Cumplimiento, sino que debe ir más allá, y centrarse en los análisis y sistemas de detección con los que cuenta el Oficial de Cumplimiento para evidenciar sus operaciones inusuales y sospechosas.

Considero importe la labor del Auditor, debido a que impondrá las observaciones correspondientes que ayudaran al Oficial de Cumplimiento a cumplir con sus funciones y responsabilidades.

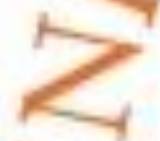

- Otros terceros: En ese rubro incluyo a los funcionarios comerciales principalmente pero también es importante mencionar a otros terceros que ayudan a prevenir las labores del Oficial de Cumplimiento como lo son sus proveedores y contrapartes que ayudan a la gestión del Oficial de Cumplimiento.

En ese sentido, si la herramienta tecnológica constante presenta fallas y se interrumpe por un periodo largó en que puedan presentarse operaciones sospechosas y que el Oficial de Cumplimiento no las pueda detectar pues la herramienta falló (riesgo operacional), en ese caso el proveedor de la herramienta debería ser partícipe de responsabilidad por no tener un buen producto.

\subsection{Responsabilidad Penal del Oficial de Cumplimiento}

El artículo $11^{\circ}$ de la Res. SBS 2660-2016 establece las 16 funciones y responsabilidades del Oficial de Cumplimiento, entre las cuales una de ellas consiste en calificar a una operación inusual como sospechosa y comunicarla a la Unidad de Inteligencia Financiera 
del Perú a través del Reporte de Operación Sospechosa y dentro del plazo que establece la Ley.

Por tanto, el no reportar una operación calificada como sospechosa por parte del Oficial de Cumplimiento, trae como consecuencia que éste cometa automáticamente un delito en la comisión de omitir la comunicación de operaciones o transacciones sospechosas, previsto y sancionado por el Artículo 5 del Decreto Legislativo $\mathrm{N}^{\circ} 1106$ que aprueba "La lucha eficaz contra el lavado de activos y otros delitos relacionados a la minería ilegal y crimen organizado".

En consecuencia a ello, analizaremos a continuación las consecuencias que trae establecer una responsabilidad penal para los Oficiales de Cumplimiento:

\subsection{Consecuencias de la Responsabilidad Penal}

Antes de dar inicio a la exposición de las consecuencias de la Responsabilidad Penal del Oficial de Cumplimiento, a continuación presento la siguiente frase:

La necesidad de promover y motivar una actitud decidida contra el lavado de activos entre los sectores vulnerables y sus operadores, ha generado también que en la legislación nacional sobre la materia, se hayan configurado para ellos, obligaciones y sanciones específicas que apuntan a consolidar su aporte diligente y proactivo a la prevención de esta clase delitos. (Prado Saldarriaga, 1991, párr.05)

La Responsabilidad Penal del Oficial de Cumplimiento resultan dos tipos de consecuencias que son las siguientes:

- Tipicidad Objetiva:

Según Hernán Hormazdbal Malaree (1989), la teoría de la tipicidad objetiva establece y alude responsabilidad penal del Oficial de Cumplimiento, el hecho de omitir una operación sospechosa pero no prevé las circunstancia de tal omisión, es decir nuestro Código Penal enmarca este delito como uno especial propio, pues según señala el hecho de no comunicar estaría incumpliendo penalmente sus funciones y obligaciones dictada en la norma de lavado de activos. 
Entonces, es una función primordial el comunicar un ROS a la UIF y el no hacerlo conlleva una conducta ilegal, lo cual se concreta en un injusto pues no identifica las posibles causas que llevaron al Oficial de Cumplimiento a omitir tal comunicación, es decir hablamos de una norma extrapenal pues compromete a la aplicación de medidas de prevención de lavado de activos con un grado dificultad imposible de predecir y más aún cuando se trata de responsabilizar a los funcionarios directamente.

La obligación legal de reportar las operaciones o transacciones sospechosas que detecten en el ejercicio regular de sus funciones recae en los sectores señalados por la ley, así como a los Euncionarios, empleados o representantes de los bancos. Por lo tanto, son todos ellos los que quedan vinculados con el cumplimiento del deber especial y quienes pueden asumir la calidad potencial de sujetos activos del delito de Lavado de activos.

Asimismo, la Res. SBS $2660-2015^{4}$ es clara al señalar que el Oficial de Cumplimiento usará su criterio y sentido común para determinar si es o no una operación sospechosa y su deber en reportarla, entonces no podríamos hablar de omisión de reportar una operación sospechosa cuando para una persona puede concluir que una operación si es sospechosa y otra persona puede analizar esa misma operación y calificarla finalmente como no sospechosa y puede darle la categoría de operación inusual.

Entonces queda claro que no podemos hablar de una omisión de reportar una operación sospechosa pues no tenemos requisitos enumerâdos que establezcan qué es una operación sospechosa o qué es una operación inusual y la norma deja al libre albedrío de los Oficiales de Cumplimiento a calificar una operación sospechosa de acuerdo al análisis realizado basándose en su experiencia, sentido

\footnotetext{
${ }^{4}$ Res. SBS 2660-2015 29.2 Cuando la empresa no se encuentre en la capacidad de cumplir con las medidas de debida diligencia en el conocimiento del cliente debe proceder de la siguiente manera: i) no iniciar relaciones comerciales, no efectuar la operación y/o terminar la relación comercial iniciada; y/o ii) evaluar la posibilidad de efectuar un reporte de operaciones sospechosas (ROS) con relación al cliente. 29.3 En caso la empresa tenga sospechas de actividades de LA/FT y considere que el efectuar acciones de debida diligencia alertaría al cliente, debe reportar la operación sospechosa a la UIF-Perú sin efectuar dichas acciones. Estos casos deben encontrarse fundamentados y documentados.
} 
común, lógica, criterio y otros argumentados que van de acuerdo a su personalidad como persona y profesión.

- $\quad$ Tipicidad Subjetiva:

En este supuesto el delito requiere dolo o intención, es decir que el Oficial de Cumplimiento se une con el lavador para encubrirlo y dejar que los productos y servicios que brinda el Banco sean utilizados para actos ilícitos.

Así también se habla de una tipicidad subjetiva cuando sin confabular con el lavador, sabe que dentro de su institución están lavando dinero pero no reporta tales operaciones por temor o por la indebida aplicación del sistema de prevención de lavado de activos.

En ese contexto, es importante indicar que los actores importantes para la gestión de riesgos de lavado de activos, son los funcionarios que mantienen contacto directo con los clientes pues ellos son los que realmente conocen las necesidades de los clientes y aprovechan estas circunstancias para sorprender a los Oficiales de Cumplimiento y permitir que los clientes realicen operaciones inusuales o sospechosas encubriéndolos con información falsa de difícil verificación para alertar al Oficial de Cumplimiento.

En este punto se vulnera muy fácilmente los sistemas de prevención, es por ello la importancia de incluir a los funcionarios bancarios como responsables directos o indirectos ante casos de lavado de activos que se presenten dentro de las instituciones financieras.

Considero importante que exista una tipicidad subjetiva cuando el Oficial de Cumplimiento es autor directo o cometió el delito dolosamente, sin embargo para aplicar este supuesto se debería tener un marco normativo claro que determine en qué supuestos el Oficial de Cumplimiento actuó con dolo, pues el pretender involucrar al Oficial de Cumplimiento por fallas de terceros o porque el Funcionario Comercial escondió la información o la falsifico para que el Oficial de Cumplimiento no pueda detectar la operación sospechosa, no debería 
involucrarse al Oficial de Cumplimiento en el proceso penal que se lleve a cabo a una persona por lavar activos.

\subsection{Conductas de terceros y fallas en los sistemas}

La conducta de terceros, en particular la de los Funcionarios que se encuentran a cargo de las cuentas de los clientes, pueden ocasionar que el Oficial de Cumplimiento comenta actos en contra de su gestión, debido a que errores o mala información proporcionada por los Funcionarios Comerciales podría resultar en la omisión de operaciones sospechosas y por consiguiente conllevaría a que el Oficial de Cumplimiento incumpla con sus obligaciones y responsabilidades.

Asimismo, ante) fallas de los sistemas o software sobre los que se sustenta las plataformas del core bancarios puede arrojar diferentes maneras de no reportar operaciones o transacciones sospechosas, las cuales, siempre mostraran como responsảble al Oficial de Cumplimiento y a la entidad bancaria, es por ello que no se debería castigar el no reportar una operación sóspechosa por el hecho de que un software de alertas de lavado de activos, no avisó al Oficial de Cumplimiento sobre alguna transacción inusual del cliente y por tanto no se puede prever tal situación.

En ese orden de ideas, la conducta errónea de terceros y/o la fallas en los sistemas, donde el Funcionario bancario actúa sin tomar en cuenta los cuidados propios que corresponden a las circunstancias especiales de la debida diligencia y conocimiento del cliente, repercute en la materialización de la conducta omisiva del Oficial de Cumplimiento; es decir, Pérez y Vega (2006) aluden que:

La comisión o acción siempre fue considerada como el punto de partida para la definición de delito, y como única forma de conducta en la comisión de hechos delictivos. Los delitos por omisión traen aparejados sus propios elementos de tipicidad, antijuricidad y culpabilidad, aunque en numerosos casos tienen puntos de contacto con la comisión, pues como ya decíamos, ambas formas de conducta no se niegan, es solo que cada una por separado guarda sus características para su posterior identificación. Son varias las reglas con relación a este aspecto, sobre todo, las que hacen típico cualquier comportamiento 
omisivo, ya sea por omisión propia o impropia, la manera en que fueron estudiadas la antijuricidad y la culpabilidad para este tipo de delito. (p. 1 y p.2).

Los software creados para evitar el lavado de activos son vulnerables y no son infalibles, he ahí la función de los Oficiales de Cumplimiento para completar con la debida información estos sistemas pero la información es enviada por los funcionarios bancarios, por ende al enviar información falsa o errada, quebrantan los software por más especializados que puedan ser, lo que resulta que por conducta u omisiones de terceros, los Oficiales de Cumplimiento enfrenten contingencias legales.

\subsection{Responsabilidad Administrativa y Civil}

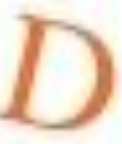

Se dice que los Oficiales de Cumplimiento tienen una responsabilidad tripartita pues ya he explicado la Responsabilidad Penal y ahora paso a detallar las otras dos responsabilidades inherentes al puesto que son la administrativa y civil.

Administrativamente el Oficial de Cumplimiento es responsable por los actos de gestión que realiza para el cumplimiento de sus funciones, es decir al ser el funcionario que tiene enlace directo con el regulador y supervisor, se encuentra llamo a sanciones y multas por las comunicaciones o informes que deba presentar dentro de los plazos establecidos en las normas.

Asimismo, como responsable de la implementación del sistema de prevención de lavado de activos, asume directamente las multas impuestas por no cumplir con la implementación señalada en norma, es por ello que una de las responsabilidades enmarcadas al Oficial de Cumplimiento es la administrativa.

Por otro lado, el Oficial de Cumplimiento es responsable civilmente por los reportes que "secretamente" elabore de posibles clientes que se encuentren inmersos de delitos precedentes al lavado de activos.

En ese orden ideas, el Oficial de Cumplimiento tiene la facultad de ordenar la medida preventiva del cierre de cuenta de ahorro o cancelar productos activos (tarjeta de crédito, préstamo personal, crédito hipotecario, etc) cuando haya encontrado indicios o presume que un cliente se encuentre realizando operaciones inusuales que no se encuentren 
dentro del ordenamiento jurídico normal o que salgan de los parámetros de transacciones estimados del cliente.

Sin embargo al dictar esta medida, el cliente puede tomar represarías y demandar por daños y perjuicios al Oficial de Cumplimiento pues la medida tomada por éste, le ha causado un daño al no permitirle tener acceso a una casa o a una tarjeta de crédito dejándolo desamparado ante la sociedad.

Ante estos hechos, el rol de los funcionarios que tienen el trato directo con el cliente es fundamental, pues ellos deben de prever que la información declarada por los clientes será verdadera y transparente con la finalidad de prevenir conductas ilícitas dentro de las instituciones, por otro lado el rol del regulador, que más adelante se explicará, es de vital importancia también, pues el reporte de operación sospechosa enviado por el Oficial de Cumplimiento en forma secreta debe permanecer bajo estrictas medidas de confidencialidad para salvaguardar su integridad y riesgos, sin embargo los clientes demandan a los Oficiales de Cumplimiento bajo la responsabilidad civil de éstos por haber ordenado el cierre de cuentas y/o cancelar los productos que mantenía en la institución financiera.

Finalizando el primer capítulo, a continuación se presenta la entrevista al Oficial de Cumplimiento del Banco Scotiabank, con la finalidad de conocer su punto de vista sobre los temas tratados en el presente capítulo.

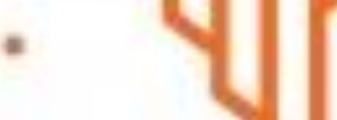

Entrevista a Antonio de la Haza Barrantes, Funcionario de Cumplimiento del Banco Scotiabank del Perú:

1. Existe una verdadera protección a los Oficiales de Cumplimiento, en cuanto a la reserva y confidencialidad sobre su nombre y funciones?

Indiscutiblemente hoy el Oficial de Cumplimiento cuenta con una mayor protección que en años anteriores, no es frecuente ver su nombre en los medios de comunicación escritos ni tampoco que sea citado por el Poder Judicial para declarar en algún proceso de naturaleza penal. 
Sin embargo, estimo que siempre se puede hacer más con el objetivo de brindarle algún tipo de protección adicional porque es una mejora constante, por ello estimo que es relativa la reserva de identidad.

Considero que la mejor protección que se le puede brindar a un Oficial de Cumplimiento es hacer conocer, educar en la opinión pública que el Oficial de Cumplimiento no califica ningún tipo de operación como dolosa vinculada al sistema financiero, sino que cumple funciones específicas administrativas vinculadas al sistema de prevención de lavado de activos y que la labor de la constitución de la prueba penal por la comisión de un hecho delictuoso está a cargo de la Unidád de Inteligencia Financiera del Perú (UIF)

\section{Considera usted que se debe eliminar la Responsabilidad Penal por Culpa del Oficial de Cumplimiento? Qué ventajas o desventajas cree Usted que pueda generar en el sistema de prevención de LAFT la eliminación de la Responsabilidad por Cúlpa del Oficial de Cumplimiento?}

Estimo que no es necesario eliminar la responsabilidad penal por culpa del Oficial de Cumplimiento en la medida que se comprenda que es por hecho propio, no por un tercero, lo cual es conforme a lo planteado por el D. Leg. 1106.

Por otro lado, para que incurra en responsabilidad es necesario contar con el informe del regulador Unidad de Inteligencia Financiera UIF con el propósito de contar con la prueba técnica para acreditar el tipo penal no es suficiente la acusación fiscal.

Mi propuesta es que el Oficial de Cumplimiento debe ser un director de las empresas del sistema financiero no un empleado, ello garantiza que los intereses de los accionistas estarán siempre protegidos y no como se observa en muchas empresas que el Oficial de Cumplimiento es una empleado con escasos recursos materiales.

3. El Oficial de Cumplimiento debe ser un investigador privado o un funcionario bancario que implemente un sistema de prevención de lavado de activos? 
Debe ser por un tema de especialidad, no puede ser ni un investigador ni un simple empleado, debe ser el Oficial de Cumplimiento aquella persona que reúne los requisitos de liderazgo, compromiso, integridad, capacidad, conocimiento de la institución y experiencia.

\section{En caso se otorgue a la UIF la facultad para poder levantar el secreto bancario de las personas, cree Usted que esta medida fortalecerá los sistemas de prevención de lavado de activos?}

Hoy en la mayoría de los países el secreto bancario es de naturaleza relativa, se abandonó el carácter absoluto del mismo.

Dentro de dicha lógica conceptual es aceptable el acceso del secreto bancario por parte de la Unidad de Inteligencia Financiera en la medida que tenga un conducto regular de solicitud debiendo ser el mismo el Poder Judicial.

Dicha solicitud puede ser anterior o posterior al haber accedido a cierta información protegida, al considerarse que no es titular del mismo al no haber sido reconocido así por la Constitución de la República.

Debiendo ser:

Solicitud previa para el levantamiento del secreto bancario, al juez, estableciendo un proceso ejecutivo para resolver por parte de la autoridad.

\subsection{Conclusiones del Primer Capítulo}

- De acuerdo a lo que he comentado en el presente capítulo, estoy seguro que realizar la modificación del artículo $5^{\circ}$ del DL 1106 , respaldaría las funciones y responsabilidades de los Oficiales de Cumplimiento, pues no ejercerían sus obligaciones por cumplir con la norma y reportar para no caer en la omisión, sino que tendrían una base normativa que les sirva de sustento para realizar sus investigaciones e análisis interno, de tal manera que puedan elaborar reportes de operaciones sospechosas sin temor a represalias. 
- Otra conclusión importante es la de involucrar a terceros en los sistemas de prevención de lavado de activos, es decir considero muy importante incluir a los funcionarios bancarios, auditores internos y externos en la modificación del artículo $5^{\circ}$ analizado en el presente trabajo, pues reforzaría la labor que estos terceros desempeñan y haría que sean responsables por las funciones que realizan.

- Finalmente, he enumerado en el segundo párrafo del artículo a modificar, a los principales responsables de las organizaciones que deben velar por el buen funcionamiento de los sistemas de prevención de lavado de activos, de tal manera que no exista un vacío normativo en caso exista un caso en que se pretenda involucrar a una sola persona cuando en realidad son todos los miembros que laboran en una compañía los responsables por evitar el blanqueo de dinero.

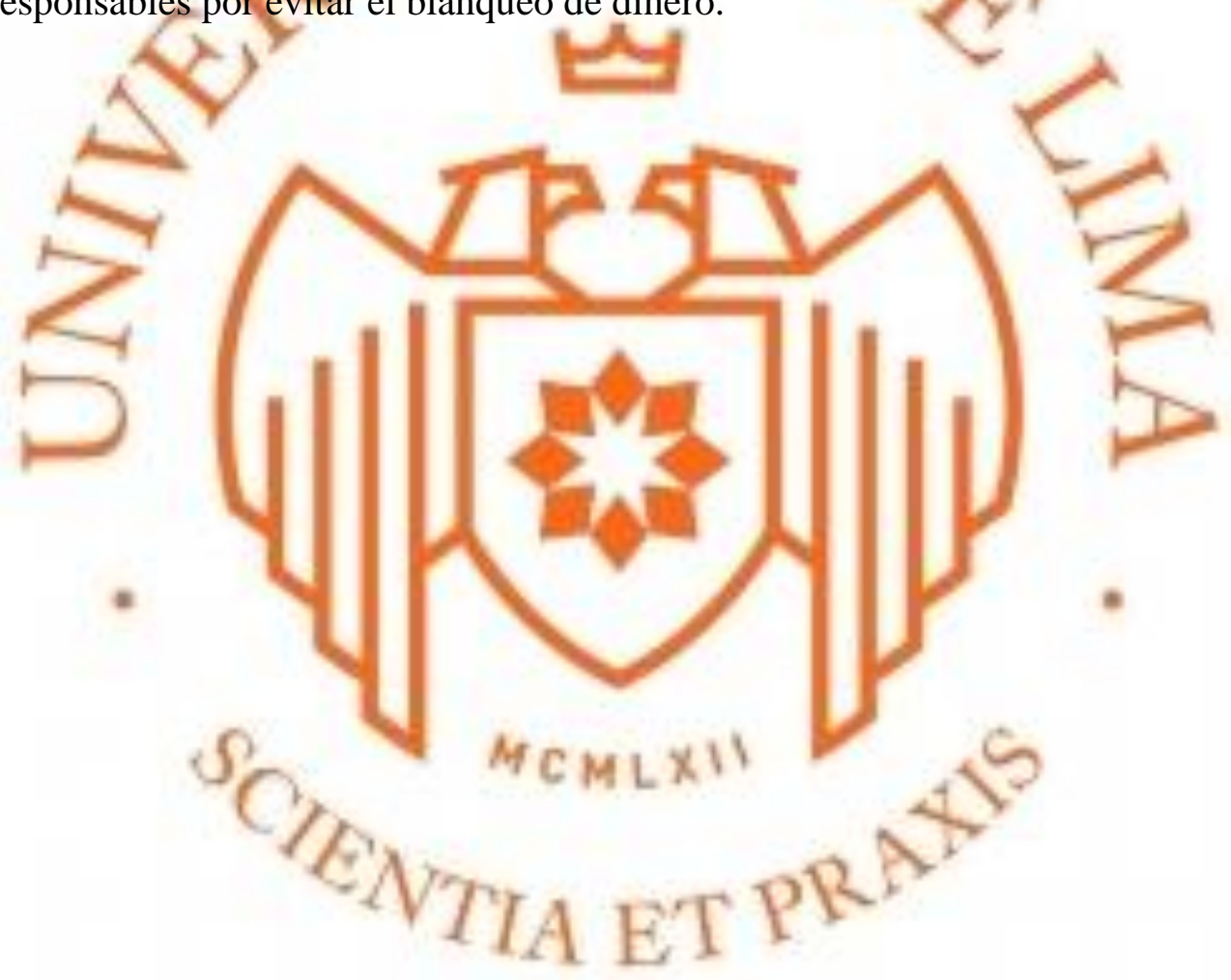




\section{CAPITULO II: EL ROL DE LAS AUTORIDADES EN LOS SISTEMAS DE PREVENCIÓN DE LAVADO DE ACTIVOS}

\subsection{Lineamiento de los Fiscales y Jueces}

El trabajo y resultados de los sistemas de prevención de lavado de activos y del financiamiento del terrorismo de las instituciones del sistema financiero sirven de base para las investigaciones realizadas por el Ministerio Público y el Poder Judicial, debido a que los Bancos son la principal fuente de información para las pesquisas que realizan las autoridades competentes dictaminen acusaciones o sentencias contra los criminales que comenten actos delictivos para el blanqueo del dinero.

Es por ello, que el lineamiento de los fiscales y jueces debe estar coordinado con los Oficiales de Cumplimiento, a través de la Unidad de Inteligencia Financiera, y deben resguardar la información que es emanada de los Bancos.

Si los Bancos no van a gozar de respaldo legal y van a estar involucrados en los medios de comunicación arriesgando su imagen y riesgo reputaciones entonces no estarán dispuestos a colaborar con las autoridades judiciales y por el contrario internamente manejarán sus políticas en cuanto a la situación de los clientes que puedan estar lavando dinero dentro de su institución.

En ese sentido, las autoridades deben resguardar y proteger a los Oficiales de Cumplimiento, puesto que ellos son los que proveen la información mediante los reportes de operaciones sospechosas a la Unidad de Inteligencia Financiera, quien analiza la información y la remite a las autoridades competentes.

\subsubsection{Deber de reserva y confidencialidad}

Resulta de vital importancia que los Fiscales y Jueces guarden la absoluta reserva y confidencialidad sobre los reportes de operaciones sospechosas que emiten los Oficiales de Cumplimiento, debido a que divulgar la información reportada pone en peligro la 
integridad de los Oficiales de Cumplimiento puesto que ellos son los que literalmente inician la denuncia contra personas y/o empresas que aparentemente estarían delinquiendo y serían incriminados en las investigaciones por cometer el delito de lavado de activos y el financiamiento del terrorismo.

En consecuencia a ello, el artículo 58 de la Resolución SBS 2660-2015, que aprueba el Reglamento de Gestión de Riesgos de Lavado de Activos, señala lo siguiente:

La comunicación de operaciones sospechosas y el ROS que realizan las empresas por medio de sus oficiales de cumplimiento tienen carácter confidencial y reservado. Únicamente el oficial de cumplimiento, o de ser el caso el oficial de cumplimiento alterno, puede tener conocimiento del envío del ROS.

En consecuencia a lo comentado, en varios casos los Oficiales de Cumplimiento se han visto involucrados en procesos jurisdiccionales debido a que su identidad fue puesta al descubierto, lo que vulnera a los sistema de prevención de lavado de activos. Si bien es cierto, existen sanciones contra los sujetos obligados que no mantienen la confidencialidad de los Oficiales de Cumplimiento, no existen sanciones contra las autoridades competentes que trasgreden la garantía estricta de reserva y confidencialidad.

La Dirección de Investigación Financiera de la Policía Nacional (DINFI) indaga sospechosas transacciones bancarias realizadas por Ernesto Schütz Freundt, quien asumió la conducción de Panamericana Televisión al fugar del país su padre Ernesto Schütz Landázuri. De acuerdo con fuentes de la DINFI, las pesquisas se iniciaron a partir de una solicitud expresa de la Superintendencia de Banca y Seguros (SBS), que a su vez recibió la información del Oficial de Cumplimiento del Banco de Crédito del Perú, entidad que usó Schütz Freundt para efectuar las operaciones financieras.

Según documentos en poder del Banco de Crédito, el hijo del dueño de Canal 5 informó que recibía mensualmente 7 mil dólares como resultado de sus ganancias obtenidas de actividades empresariales. Las transferencias efectuadas por Ernesto Schütz Freundt sobrepasan los diez mil dólares. De acuerdo con la ley vigente, cuando se realizan operaciones superiores a dicha suma, el Oficial de Cumplimiento de la entidad bancaria vinculada debe de inmediato informar a la SBS del movimiento de dinero bajo observación. Las fuentes evitaron precisar las sumas movilizadas. (PNP investiga hijo de Schutz por sospechas transferencias de dinero, 2003. La República.) 
De acuerdo a lo evidenciado en los artículos de internet presentados, los sistemas de prevención de lavado de activos de los Bancos se vuelven débiles al tener Oficiales de Cumplimiento que arriesgan sus vidas al enviar sus reportes de operaciones sospechosas, más aún cuando sus nombres salen a la luz ante casos mediáticos donde se involucra mucho dinero y las partes deben realizar lo necesario a fin de evitar la cárcel. Es aquí donde no se dan garantías a los funcionarios que tratan de evitar el lavado de activos dentro de sus instituciones debido a que son incluidos dentro del proceso por delitos culposos al no reportar operaciones sospechosas.

\subsubsection{Medidas de seguridad para el Oficial de Cumplimiento}

La Unidad de Inteligencia Financiera - UIF, otorga medidas de seguridad para los Oficiales de Cumplimiento, como es el código secreto de identificación del Oficial de Cumplimiento, código secreto del Banco al que pertenece el Oficial de Cumplimiento y el uso de sistemas bajo claves secretas para enviar los reportes de operaciones sospechosas, sin embargo las medidas de seguridad descritas son vulneradas quizás por la misma UIF o por los Fiscales o Jueces pues en casos mediáticos hemos visto que los Oficiales de Cumplimiento son expuestos por errores o fallas en las instituciones antes mencionadas o por actos de negligencias de las autoridades.

Una inspección ocular a los libros de registro del Banco Continental para establecer quienes fueron los empleados que manejaron las cuentas de José Nelson Urrego fue solicitada a la Fiscalía de Drogas. La petición está orientada para poder revisar los libros de contabilidad y así establecer la forma en que fueron hechos los depósitos de Urrego, uno de los cabecillas del Cartel del Norte del Valle de Colombia. También se intenta verificar quien era el oficial de cumplimiento de la entidad bancaria al momento que Urrego abrió las cuentas. La inspección intenta establecer si los depósitos realizados por el colombiano fueron realizados a través de cheques o en efectivo. Ayer, la fiscalía y la defensa de Urrego repreguntaron a las unidades de la Policía que realizaron los informes de inteligencia del seguimiento a la red criminal. El oficial de cuentas del Banco Continental, Miguel Sierra, está detenido por no haber cerrado las cuentas de Urrego, a pesar de existir una orden de sus superiores para ello. (Díaz, 2007, párr. 1 - 6) 
En ese sentido, dado que las medidas de seguridad sobre la identificación de los Oficiales de Cumplimiento son vulneradas fácilmente, se propone modificar el artículo que responsabiliza culposamente al Oficial de Cumplimiento puesto que no se le sancionaría por reportar operaciones sospechosas y harían que los Oficiales de Cumplimiento estén seguro de reportar y de la información que reportan y con ello se lograría eficiencia y eficacia en los sistema de prevención de lavado de activos y del financiamiento del terrorismo.

\subsection{Auditoría Interna y Auditoria Externa}

En toda organización, y más aûn en las que cuenta con un regulador según el sector en que se desarrolle de acuerdo a su -objeto social, es relevante la importancia de las auditorías internas y externas, pues éstas buscan encontrâr las fallas en los sistemas de prevención de lavado de actiyos con la finalidad de que los Oficiales de Cumplimiento corrijan y mejoren los sistemas. En ese orden de ideas, las auditoras externas no cumplen su verdadero rol pues todos los ãnos los Bancos son sancionados administrativamente por el regulador por incumplir con las normas de lavado de activos y del financiamiento del terrorismo.

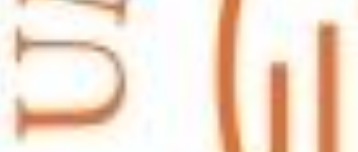

\subsubsection{Las evaluaciones al sistema de prevención de lavado de activos}

Las evaluaciones por parte de las auditorías deberían reflejar el verdadero status de los sistemas de prevención, con ello se evaluarían las exposiciones que presenta el cargo al ejercer la Oficialía de Cumplimiento de un Banco, es decir analizando el tema principal de la presente tesis, si los auditores en sus evaluaciones hubieran detectado las fallas y responsabilidades que existen al reportar operaciones sospechosas, no habría necesidad de plantear una modificación normativa pues de los informes auditables se hubiera podido ajustar la norma de responsabilidad, de tal manera que hoy en día no estaríamos discutiendo la presente realidad. 


\subsubsection{Responsabilidad de los auditores internos y externos}

El rol de la auditoría interna como tercera línea de defensa para la evaluación de la efectividad de los sistemas de prevención de lavado de activos, debe ser independiente y objetiva para ayudar a los Oficiales de Cumplimiento a cumplir con sus objetivos dentro de las instituciones financieras.

En ese sentido, todos los sujetos obligados financieros cuentan con áreas de auditoria interna que supervisan la efectividad de sistema de control interno para la prevención, detección de operaciones inusuales, financiamiento del terrorismo y en general que los productos y servicios que se prestan no sean utilizados para ocütar dinero. Es por ello, que el auditor interno, como tercera línea de defensa, ejerce su rol con independencia y efectividad, dentro del sistema de prevención; sin embargo su cargo no asume responsabilidades penales ante la detección de fallas en los sistemas de prevención.

Por otro lado, de acuerdo a nuestra normativa local todos los años los sujetos obligados financieros están obligados a contratar a sociedades auditoras externas con la finalidad de que revisen y evalúen los sistema de prevención de lavado de activos, por lo que los auditores externos elaboran sus informes con los resultados y las recomendaciones correspondientes, el cual es puesto a conocimiento de la Alta Dirección de las empresas, sin embargo en el caso de que se detecte a clientes que se encuentran lavando dinero dentro de las empresas, y los auditores externos, no pudieron evidenciar en sus informes tales situaciones, entonces amerita una responsabilidad compartida pues se asumiría que la sociedad auditora externa no cumplió su rol en la supervisión.

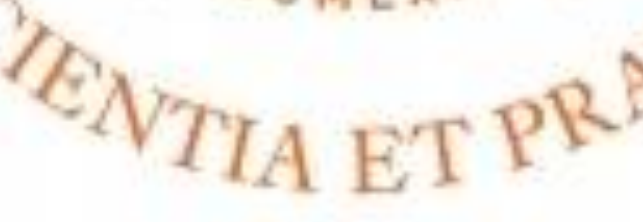


Figura 2.1.

Esquema de Tres Líneas de Defensa

Esquema de Tres Líneas de Defensa

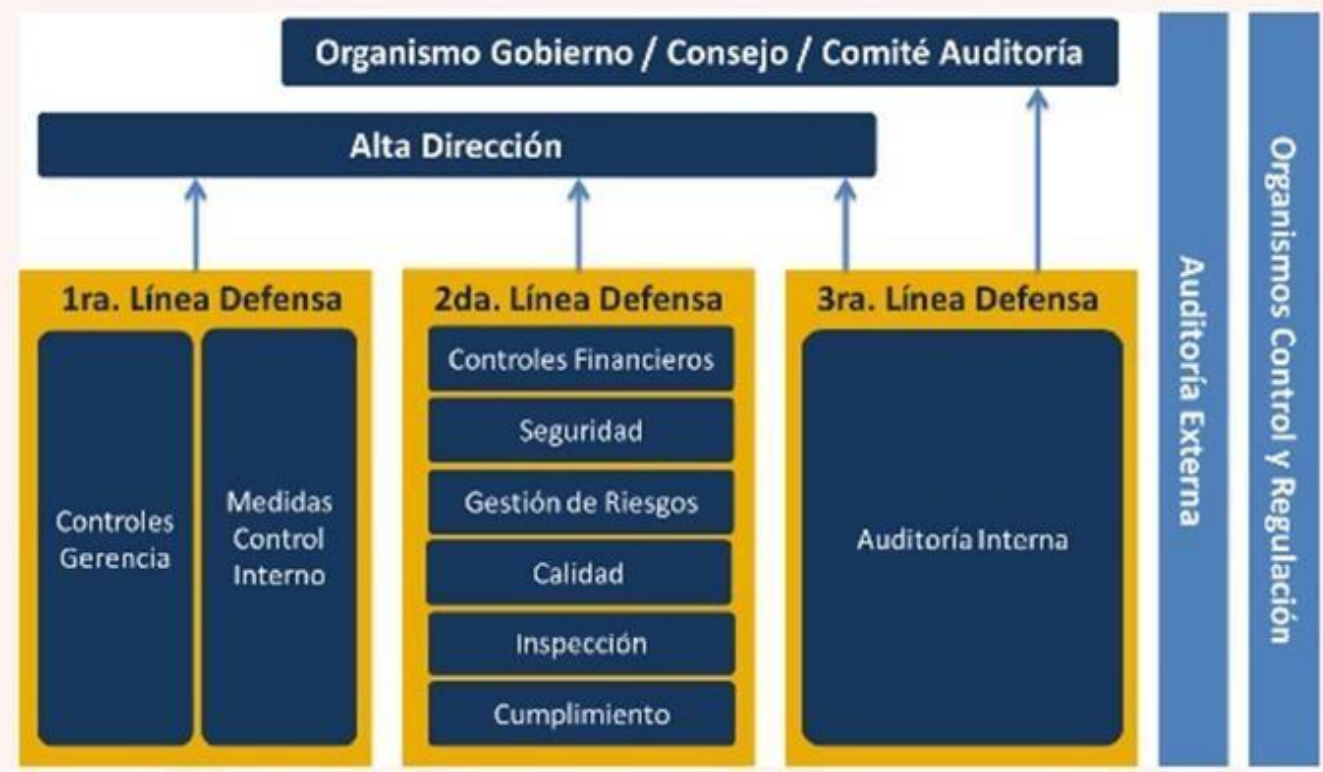

Fuente: Enric Doménech, socio de BDO Risk Advisory Services para la UNACC

La primera línea de defensa corresponde a las unidades de negocio, quienes tienen la responsabilidad de:

- Conocer al cliente, porque son quienes lo vinculan e inician la relación comercial.

- Controlan las operaciones de los clientes.

Como segunda línea, el Oficial de Cumplimiento, pues es el responsable de implementar el sistema de prevención lavado de activos de la entidad. El área de Cumplimiento asegura que los riesgos relacionados a lavado de activos sean identificados y administrados, asimismo se encarga de la supervisión continua para el cumplimiento de las obligaciones por parte de la entidad financiera así como alertar sobre las operaciones inusuales que se presenten.

Y como se ha explicado, como tercera línea la auditoría interna, quien supervisa y evalúa la efectividad de las responsabilidades del Oficial de Cumplimiento. 
A continuación se presentan dos entrevistas de expertos en la materia, por lo que podremos observar el análisis de un auditor externo y un auditor interno, y conocer desde ambos frentes cuáles son sus tendencias en cuanto a las mismas preguntas:

Entrevista a Liz Trujillo, Gerente de Auditoria en Prevención de Lavado de Activos y del Financiamiento del Terrorismo, de la sociedad auditora PriceWaterhouseCoopers

\section{1. ¿Se deben de implementar mayores medidas de seguridad para los Oficiales de Cumplimiento sobre las que ya existen?}

Mayores medidas de seguridad, no necesariamente garantizan que se lleve a cabo con eficiencia los procedimientos, muchas veces terminan siendo más barreras que limitan a que el Oficial del Cumplimiento realice procedimientos libremente, se debería fomentar al cumplimiento de las medidas actuales, ya que incrementar normas y medida de seguridad no necesariamente genera que el sistema mejore o que sea eficiente.

2. ¿Considera Usted que se debe incluir a los auditores internos como responsables penales, en el caso se compruebe que existen fallas en los sistema de prevención de lavado de activos de las empresas y que los auditores internos omitieron informar en sus informes o no lo observaron?

El auditor es responsable de realizar sú trabajo cumpliendo las normas internacionales de auditoría, que exigen que se desarrolle un trabajo bajo el principio de escepticismo profesional, si no observó una situación que debería, es porque no realizó un buen trabajo o no mitigó el riesgo de la auditoría de manera correcta.

El auditor realiza su trabajo bajo un plan, la misma que debe contener procedimientos para responder el riesgo de una mala implantación, por lo tanto no cumplir su trabajo bajo este requerimiento recibe una sanción administrativa, cabe indicar que no se puede mitigar el riesgo de auditoría a cero, todos los auditores tienen que afrontar este riesgo, además si la Gerencia omite una evidencia de auditoría y/o entrega una información 
no real limita al auditor a detectar una omisión dolosa, por lo tanto considerar una responsabilidad penal es complicado.

Entrevista al Lic. Ivan Mauricio Gomez Barrios, Auditor Interno del Banco GNB Sudameris de Colombia

1. ¿Cree usted que las auditorías externas cumplen su rol y ayudan a prevenir el lavado de activos encontrando fallas u observaciones dentro de las empresas?

La Auditoría Externa cumple su rol, de evaluación sin embargo, por no vincular alguna de responsabilidad legal sobre el trabajo efectuado puede Hegar a ser un trabajo muy superficial de cumplimiento macro sin tener en cuenta detalles relevantes que puedan llegar a convertirse en hallazgo de Lavado de Activos.

2 ¿Considera usted que se debe incluir a los auditores externos como responsables penales, en el caso se compruebe que existen fallas en los sistema de prevención de lavado de activos de las empresas y que los auditores externos omitieron o no lo observaron?

Por supuesto existen principios para la ejecución de las labores de Auditoría y entre ellos se encuentran:
a. Pericia
b. Debido Cuidado
c. Debida Diligencia
d. Idoneidad
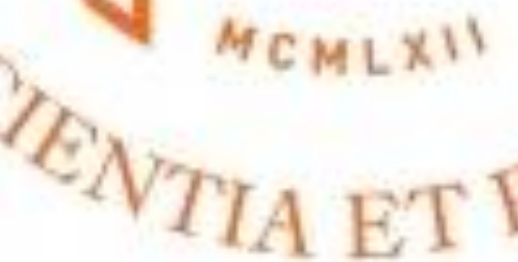

3. En caso se sancione penalmente a un Oficial de Cumplimiento, ¿Cree usted que los auditores externos deben compartir esa responsabilidad y también deberían ser sancionados por no evaluar eficientemente el sistema de prevención de lavado de activos? 
Por supuesto, es una cadena de responsabilidades que tiene que involucrar no solo a los entes de control sino áreas Comerciales, Legales, Operativas y de Representación.

\section{4. ¿La auditoría interna constituye una verdadera tercera línea de defensa en la prevención del lavado de activos? $O$, i cree usted que deben implementarse cambios o mejoras que ayuden a los Oficiales de Cumplimiento a prevenir el lavado de activos y el financiamiento del terrorismo?}

La labor de Auditoría Interna es una tabor que debe igualmente ser aplicada conforme a los lineamientos antes mencionados y procurado-lograr la generación de valor, bajo este entendido la SBS solicita una certificación del estado del funcionamiento de Control Interno en la Gestión de Prevención de Lavado de Activos; no obstante de acuerdo a factores como:

a. Grado de madurez de la entidad

b. Pericia del Auditor

c. Programas de Auditoría Exhaustivos y alineados con las mejores prácticas propuestas por GAFI y Felaban

d. Supervisión continua y niveles de aprobación para la emisión de los informes

\subsection{La Unidad de Inteligencia Financiera}
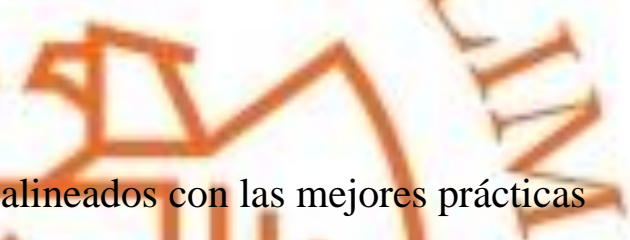

La UIF - Unidad de Inteligencia Financiera, unidad que pertenece a la Superintendencia de Banca, Seguros y AFP - SBS, principal regulador del sistema financiero peruano; es la unidad encargada de recibir los reportes de operaciones sospechosas que emiten los Oficiales de Cumplimiento de todos los Bancos con el objetivo de analizar la información y ponerla a disposición del Ministerio Público quien deberá iniciar la denuncia formal correspondiente sobre los reportados en los ROS (Reporte de Operaciones Sospechosas).

De lo descrito, es importante la participación de la UIF en la reserva y confidencialidad del nombre de los Oficiales de Cumplimiento y del contenido de los ROS, pues la UIF es quien recibe esa información y luego la canaliza hacia la Fiscalía, y es en 
este punto del traspaso de información donde se vulnera los derechos de reserva y confidencialidad de los Oficiales de Cumplimiento, poniendo sus vidas en peligro, pues la Fiscalía al formular la respectiva denuncia penal inicia la investigación sobre las personas que intervienen en los ROS y ponen al descubierto secretos informativos que no deben ser levantados.

Asimismo, luego de la formalización de la denuncia, el proceso continúa en manos del Poder Judicial quien en aras del protagonismo malicioso cita a los Oficiales de Cumplimiento para que declaren sobre los ROS que reportaron a la UIF, lo que origina un descuido legal pues el nombre "secreto" de los Oficiales de Cumplimiento, se ponen al descubierto ante los investigados o- procesados, quienes en la mayoría de sus casos son personas ligadas al mundo delictivo, quienes al enterarse que el Oficial de Cumplimiento fue el que inicio el curso de las investigaciones, toman represarías contra la integridad física o daño psicológico en contra de los citados funcionarios bancarios.

\subsubsection{Prevención del sistema de lavado de activos}

El Sistema de Prevención de Lavado de Activos y del Financiamiento del Terrorismo es el conjunto de políticas y procedimientos que se deben implementar de acuerdo a la normativa de cada país, con la finalidad de evitar que los productos y servicios que brindan los sujetos obligados, para el caso de este trabajo los Bancos, sean utilizados para blanquear dinero, esconder al verdadero beneficiario final y/o financiar grupos terroristas.

En ese sentido, la importante labor que lleven a cabo los Oficiales de Cumplimiento hará que los Bancos puedan no iniciar relaciones comerciales con personas que intentan blanquear dinero o si estas personas se encuentra dentro de las instituciones, las deberán detectar y desvincular de acuerdo al caso.

Es por ello, que fortalecer los sistemas de prevención de lavado de activos significa fortalecer también a los Oficiales de Cumplimiento, y como se los fortalece? Pues dándoles garantías y seguridad para que lleven a cabo sus funciones y responsabilidades con la absoluta confianza que el riesgo penal del cargo implica, es decir otorgar responsabilidades culposas a los Oficiales de Cumplimiento por actos que no cometieron, es ir en contra de 
sus laborales y por tanto los sistemas de prevención de lavado de activos serían vulnerables antes las personas que pretenden delinquir.

\subsubsection{Protección al Oficial de Cumplimiento}

Un pilar importante para que el sistema de prevención de lavado de activos funcione, es el Oficial de Cumplimiento, pues es la persona que lidera el sistema de prevención, es quien lo implementa y revisa que todo funcione tal cual se ha implementado.

Sin embargo, al no existir protección legal para el Oficial de Cumplimiento, no existe un sistema de prevención sólido, pues si el Oficial-de Cumplimiento envía un ROS a sabiendas que su nombre será expuesto entonces decidirá no reportar operaciones sospechosas, y en ese caso, las personas que delinquen ganarían la batalla de lavar dinero, no solo en los Bancos sino dentro de un país.

En ese orden de ideas, es de vital importancia realizar la modificación al artículo $5^{\circ}$ del Decreto Legislativo $\mathrm{N}^{\circ} 1106$, pues con ello se lograría robustecer los sistemas de prevención de lavado de activos, otorgándole seguridad jurídica a los Oficiales de Cumplimiento, quienes son los funcionarios bancarios que se encargan de informar a las autoridades competentes el trabajo que realizan en la detección de operaciones inusuales o sospechosas.

Finalizando el capítulo segundo, a continuación se presenta la entrevista de un abogado especializado en la materia, quien revela puntos importantes tratados en el presente trabajo:

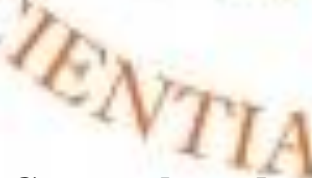

Entrevista al Dr. Carlos Caro - abogado especialista en delitos económicos y lavado de activos

\section{En el supuesto que el Oficial de Cumplimiento omita por negligencia o sin dolo, comunicar una operación sospechosa, ¿debe ser sancionado penalmente?}

El legislador peruano ha dispuesto a través del artículo 5 del DL 1106 que el Oficial de Cumplimiento sí responda penalmente en los casos de omisión por culpa. Sin embargo, de 
la lectura del Plan de Investigación enviado, se plantea la duda bajo los siguientes términos: si este Oficial debe responder por culpa bajo la premisa que si otro funcionario del Banco por ejemplo- comete negligencia u omite la debida diligencia con los clientes, y como consecuencia de ello, el Compliance Officer no debe responder porque no cometió el hecho punible y en consecuencia no puede recaer sobre él un resultado desfavorable.

En atención a ello, debemos remitirnos a los conceptos básicos de culpa. La imputación por culpa al Compliance Officer no se basa en el hecho cometido por un tercero (así actúe también de forma negligente), aceptar ello sería retrotraernos a la proscrita responsabilidad objetiva del Derecho penal. Un compliance officer responderá por culpa, porque él mismo (y no otro) no tuvo la debida diligencia que se le exigía o no tuvo el cuidado debido en la realización de sus funciones. La organización defectuosa la deberá hacer el mismo Compliance Officer y no un tercero.

Si partimos sobre la base que la función del Compliance Officer es informar (para nuestro caso de actividades sospechosas, porque recordemos que este Oficial puede tener muchas más funciones); el no hacerlo puede ser a través de dos formas: dolosa y culposa; y de acuerdo a la teoría del Derecho penal son ambas válidas plenamente.

La respuesta sobre si debe o no responder penalmente en omisión por culpa, se tiene que explicar también en términos criminológicos. Es cierto sostener que el parámetro de la responsabilidad penal siempre latente sobre la cabeza del Compliance Officer puede afectar directamente a su labor diaria, pero para ello debemos ser claros en señalar que la responsabilidad penal es personal y ceñirnos a la teoría general del Derecho penal.

\section{2. ¿Considera usted que se debe eliminar la responsabilidad penal por culpa del Oficial de Cumplimiento? ¿Qué ventajas o desventajas cree que pueda generar en el sistema de prevención de lavado de activos la eliminación de la responsabilidad por culpa del Oficial de Cumplimiento?}

Si se elimina la responsabilidad por omisión por culpa, existirá un vacío legal, pues como hemos señalado en casos de defectuosa organización por culpa del Compliance Officer no habrá responsabilidad penal ni sanción para nadie. Así, habrá una puerta abierta en aquellos 
casos donde no se le impute dolosamente y como consecuencia, todos esos casos recaerán en atípicos. En un país como el nuestro donde se busca garantizar y frenar la comisión del delito de lavado de activos, estamos dejando un flanco abierto a que se cuelen por esa vía dichos actos. Desde luego, partiendo de un punto de vista garantista para la labor del Compliance Officer, quien día a día tiene que lidiar con este tema, resulta beneficioso pues se le está dejando de sancionar penalmente, pero tendríamos que preguntarnos hasta qué punto esa flexibilidad punitiva, afectará el sistema antilavado mismo.

\section{3. ¿El Oficial de Cumplimiento debe ser un investigador privado o un funcionario bancario que implemente un sistema de prevención de lavado de activos?}

Esta es una gran discusión que los mismos modelos de prevención no llegan a responder del todo. Aquí debemos diferenciar dos cuestiones, el primero sobre si ¿El compliance Officer debe ser un funcionario que trabaje externa o internamente?, y el segundo sobre si ¿él mismo debe crear el sistema de Prevención de lavado y el mismo hacerlo funcionar o no?. Sin embargo, no estoy de acuerdo con la denominación de investigador privado, pues el Compliance Officer tiene un determinado perfil y funciones establecidas, las mismas que se alejan a la de un investigador privado.

Volviendo a la pregunta, hay algunos autores que postulan que el Compliance Officer que implemente el Sistema de Prevención de lavado no debe hacerlo funcionar, sino otro. La razón es por la contaminación que crea el hacerlo. Otros son de la idea de que el Compliance Officer debe participar en todo el proceso del Programa de prevención, desde la creación pasando por la implementación porque nadie mejor que él sabrá de qué va el Programa de Prevención y eso hará que el programa sea más efectivo.

De la misma manera, hay opiniones diferentes sobre la posición jurídica de este funcionario en el Programa de Prevención (ya sea interno o externo). Aquellos, que señalan que el Compliance Officer debe trabajar directamente en el empresa o banco por ejemplo, se basan en que sólo así podrán conocer los problemas del día a día y podrán informar teniendo de primera fuente los datos, mientras que los que rechazan esa día se basan en la pérdida de objetividad y contaminación con otras actividades siendo el resultado final, quizás no el más fiel con la realidad. Desde luego, la posición que este Compliance 
Officer (más o menos conocimiento) repercutirá necesariamente al momento de la imputación penal, cuando la hubiese.

4. En su opinión, ¿debería darse una norma clara, completa y plena como para impedir que, a pretexto de su interpretación, se responsabilice al oficial de cumplimiento por actos que otros cometieron dentro de su institución?

Nuevamente, no se trata que el Compliance Officer responda por los hechos (negligentes o no) de terceros. De hecho, en todo nuestro sistema jurídico penal eso no ocurre, ni un Compliance Officer ni un Funcionario Público, ni una persona natural puede ni debe responder por el hecho cometido por un tercero.

Ahora bien, respecto a la implementación de normas para el tema de la regulación de funciones del Compliance Officer en el caso de lavado de activos, resulta un tanto diferente al Compliance Officer de una empresa, pues vemos que el primero tiene regulados sus funciones $\mathrm{y}$ atribuciones, mientras que de acuerdo al espíritu del Compliance, la autoregulación se da caso por caso (claro está respetando el marco normativo general). Si nuestro modelo ha optado por una regulación de las atribuciones del Complianc Officer, desde luego estas deberán ser claras y completas, de manera que este personaje conozca lo permitido y no de sus funciones, de manera que no incurra en ilícitos -ni siquiera en modalidad culposa.

\subsection{Conclusiones del segundo capítulo}

- De acuerdo a lo expuesto en el presente capítulo, puedo concluir que la función de los fiscales y jueces es fundamental para la prevención del lavado de activos, no solo porque ellos son las autoridades encargadas de perseguir el delito sino que el respaldo que le otorguen estas autoridades a las labores del Oficial de Cumplimiento va a servir para que las investigaciones por este tipo de delitos sean confidenciales y reservadas.

- Por otro lado, la función de la Unidad de Inteligencia Financiera va ser determinante pues ellos son el nexo o enlace entre el reporte de operación sospechosa presentado por 
un Oficial de Cumplimiento y las autoridades fiscales y jueces quienes son los que reciben los reportes de operaciones sospechosas.

- De no existir sinergias y colaboración entre las entidades gubernamentales que he mencionado, los Oficiales de Cumplimiento que están enmarcado dentro del sector privado no podrán ejercer las labores encomendadas a cabalidad y el delito de lavado de activos seguirá creciendo en nuestro país.

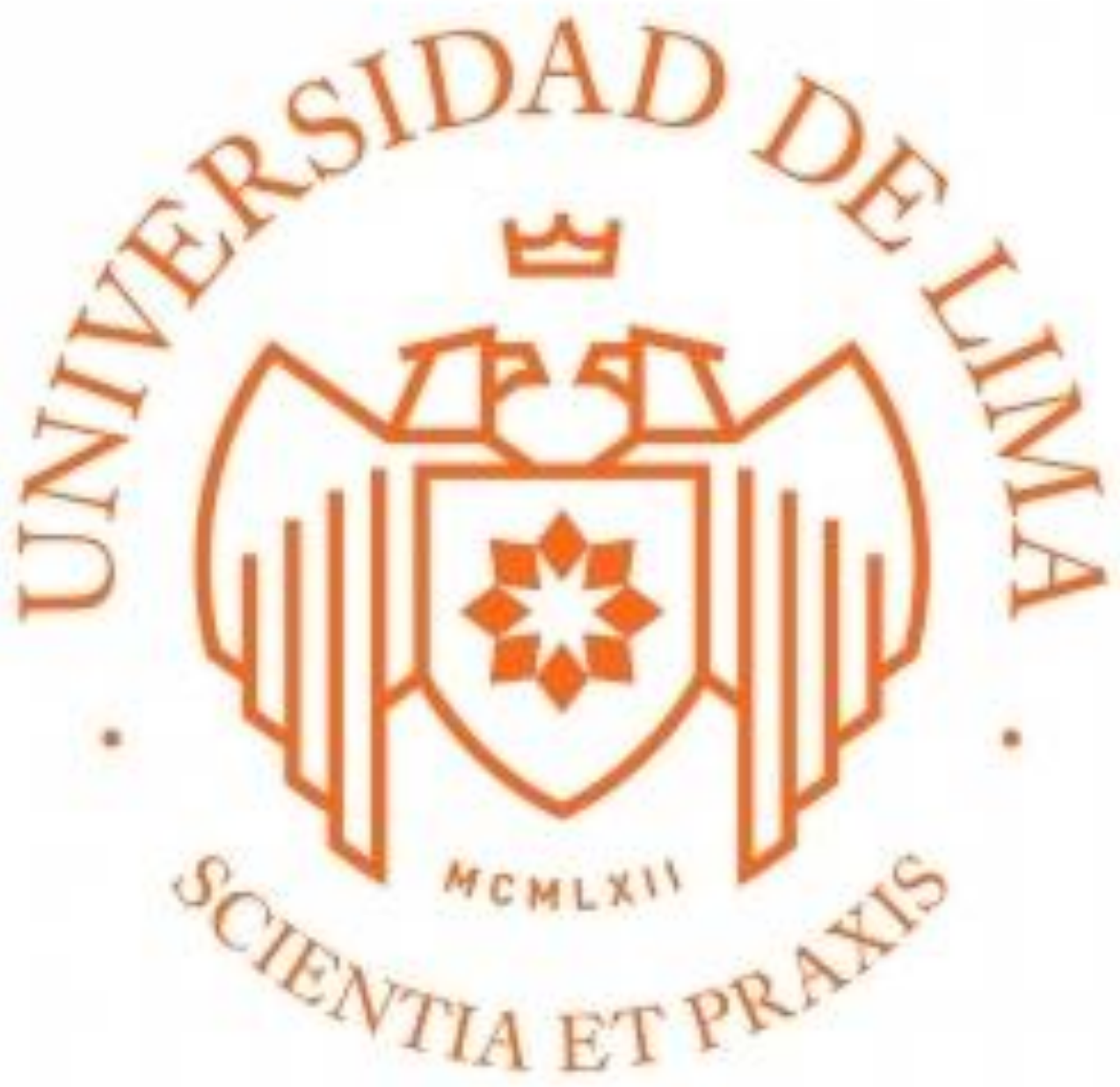




\section{CAPITULO III: CÓMO MEJORAR LOS SISTEMAS DE PREVENCIÓN DE LAVADO DE ACTIVOS}

\subsection{Análisis y mejoras como resultado de la modificación de la responsabilidad penal del Oficial de Cumplimiento}

Lograr eliminar la responsabilidad penal por Culpa para el caso de los Oficiales de Cumplimiento fortalecería los siguientes puntos:

a) Mantener la confidencialidad del nombre del Oficial de Cumplimiento: Puesto que al pretender involucrar a los Oficiales de Cumplimiento en investigaciones por no haber reportado operaciones sospechosas de un cliente acusado de cometer algún delito precedente de lavado de activos, conllevaría a que en ese caso se publique el nombre del Oficial de Cumplimiento y por consiguiente todo el sector externo, es decir clientes del Banco y público en general, sabrían quién es el Oficial de Cumplimiento de tal institución y para las personas que delinquen, se les daría una ventaja para que puedan usar sus medios ilícitos en la institución donde conocen quien es la persona que los perseguiría en caso los detecten.

b) Consolidaría la función del Oficial de Cumplimiento: Dado que los Oficiales de Cumplimiento, son los funcionarios encargados de vigilar y prevenir el lavado de activos dentro de las entidades, cumplen una función sensible y crítica pues sus informes, denominados Reporte de Operaciones-Sospechosas - ROS, podrían dar inicio a una denuncia penal y posterior condena en el ámbito judicial.

En ese sentido, la labor de los Oficiales de Cumplimiento se ve interrumpida por represarías que puedan realizar las personas involucradas en los ROS, por lo que eliminar la responsabilidad por culpa en sus responsabilidades haría que los ROS contengan información de los clientes o personas que se encontrarían blanqueando dinero dentro de su institución, sin embargo por el temor a ser 
víctimas de amenazas no reportan debidamente para no estar implicados en futuras denuncias.

c) Reforzaría los Reportes de Operaciones de Sospechosas: Como ya se ha comentado, la función principal del Oficial de Cumplimiento es reportar mediante ROS, los indicios de lavado de dinero dentro de su institución, no obstante a ello; el no reportar o reportar tardíamente ocasionaría que el "negligente" Oficial de Cumplimiento sea involucrado en investigaciones penales que podrían terminar en condenas penales tal y como se ha evidenciado en puntos anterior como lo ocurrido en Paraguay, USA, etc.

En estos casos, el no eliminar la responsabilidad culposa ocasiona actualmente dos escenarios: (1) reportar todo lo que sea, es decir los Oficiales de Cumplimiento con el fin de evitar denuncias por responsabilidades culposas al no reportar, se ven en lả obligación de reportar todo lo que sea posible, lo que ocasiona que sus informes en la mayoría de casos "sean sin sustento y nô culminen en una verdadera investigación; y (2) reportar verdaderamente con sustentos que evidencien una buena investigación pero con el posible temor a que sean involucrados en la misma o sea de conocimiento público su nombre y por consiguiente sea víctima de las personas que reportó.

\subsection{Mejoras en el Sistema de Prevención de Lavado de Activos}

El objetivo de la presente tesis ha sido plantear las contingencias sobre las funciones y obligaciones que tienen a su cargo-los Oficiales de Cumplimiento, dados los crecientes acontecimientos de corrupción, sobornos y delitos precedentes de lavado de activos que suceden en nuestro país y en el mundo.

Es por ello, que planteo una modificación normativa al artículo $5^{\circ}$ del Decreto Legislativo $\mathrm{N}^{\circ} 1106$ que aprueba "La lucha eficaz contra el lavado de activos y otros delitos relacionados a la minería ilegal y crimen organizado". De tal manera que si abarcamos el problema de fondo, que es la inseguridad o inestabilidad legal del Oficial de 
Cumplimiento, podremos fortalecer una carrera profesional que muy pocos en la actualidad son amigables a ello, debido a la responsabilidad penal que conlleva.

Existen autores que han desarrollado diversos conceptos sobre el trabajo del Oficial de Cumplimiento, otros han escrito teorías sobre la responsabilidad de omitir reportes de operaciones sospechosas, sin embargo al embarcarme en este trabajo, no he encontrado algún libro o trabajo que hable directamente sobre el peligro que representar a los Oficiales de Cumplimiento cargar con una responsabilidad penal en la que muchos casos pueden presentarse por actos de terceros que trabajan con él en la misma institución pero que escondieron o simularon información para que el Oficial de Cumplimiento no pueda reportar operaciones sospechosas y se configure el delito por omisión de reportar operaciones sospechosas.

En ese séntido, lo que trato de explicar en el presente trabajo, es dar a conocer las funciones y responsabilidades del Oficial de Cumplimiento y los riesgos a los que se enfrenta, mayor aun cuando se trata de Oficiales de Cumplimiento que laboran en el sistema financiero, pues una institución bancaria desde que abre una agencia bancaria para atender al público corre riesgos inherentes al negocio, como robos, asaltos, estafas, etc. Es por ello, que el riesgo de lavado de activos en los Bancos es un riesgo inherente porque siempre va a existir y he aquí la función del Oficial de Cumplimiento, quien es el encargar de mitigar estos riesgos controlándolos y disminuyéndolos pero no podrá eliminarlos.

En ese orden de ideas, las mejores planteadas en el presente documentos son los siguientes:

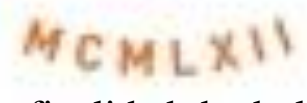

a) Modificación normativa con la finalidad de darle mayor seguridad a la función del Oficial de Cumplimiento:

La modificación planteada sobre el artículo $5^{\circ}$ del Decreto Legislativo $\mathrm{N}^{\circ} 1106$ que aprueba "La lucha eficaz contra el lavado de activos y otros delitos relacionados a la minería ilegal y crimen organizado", debe darse con el fin de contribuir a la seguridad del Oficial de Cumplimiento y que éste reporte sin temor a represarías.

En la actualidad, y bajo mi experiencia, he visto casos en que los Oficiales de Cumplimiento no reportan a personas o clientes que creen que estén lavando dentro 
de su institución por el temor a no tener represarías futuras, no solo en el ámbito administrativo o civil, sino en el ámbito penal sobre todo, pues el reportar una operación sospechosa implicaría en muchos casos que el nombre del Oficial de Cumplimiento salga a la luz, o peor aún que se vea inmerso en procesos penales por el hecho de emitir un reporte, debido a que un Fiscal o Juez pueden citarlo a declarar con el objetivo de que precise la información que contiene su reporte de operación sospechosa.

Modificando el artículo planteado, se podrán atenuar riesgos para los Oficiales de Cumplimiento, quienes son funcionarios de una institución privada y no son autoridad obligada a denunciar y perseguir a personas que delinquen.

Asimismo, el planteamiento sobre la modificación al artículo $5^{\circ}$ del Decreto Legislativo №1106 que aprueba "La lucha eficaz contra el lavado de activos y otros delitos relacionados a la minería ilegal y crimen organizado", va ser un camino largo que recorrer pues el Congreso de la República del Perú es la institución que debería plantear la situación y evidenciar el cambio normativo, sin embargo ésta va ser una dura batalla pues hasta que no se presente un caso mediático que involucre en los medios de comunicación a un Oficial de Cumplimiento en estado de desprotección por haber sido víctima de amenazas contra su vida por haber reportado a algún criminal o a una organización delincuencial, no va ser posible poner en la mesa esta contingencia que fundamento en el presente trabajo.

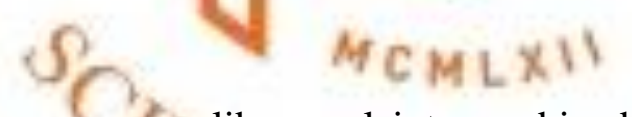

b) Promulgar normas que liberen el intercambio de información entre las entidades gubernamentales, de tal manera que sea accesible conocer los antecedes de las personas:

Ante las nuevas leyes emitidas por la SBS con la finalidad de cumplir regulaciones externas, se han dictados normas importantes que ayudan a la Unidad de Inteligencia Financiera a profundizar sus investigaciones, como lo es el levantamiento del secreto bancario. En ese sentido, si bien es cierto que dentro del paquete legislativo promulgado por el presente gobierno se dictaron normas que 
ayudan a la UIF a llevar a cabo sus investigaciones, debo señalar algo que no se ha dicho:

"Los Bancos envían sus informes a la UIF levantando el secreto bancario de sus clientes"

Considero que la nueva normativa se ha realizado con el objetivo de formalizar un tema que ya se venía dando, pues los Oficiales de Cumplimiento al emitir sus reportes de operaciones sospechosas, consignan los movimientos de dinero en que los usuarios o clientes han realizado ante esta clase de operaciones, asimismo los Bancos emiten reportes a sus reguladores (SBS y UIF), sobre las operaciones de los ejecutantes, beneficiarios y ordenantes que realicen cualquier tipo de transacción dentro de su institución.

En ese sentido, la preocupación que mostraba la UIF al decir que no contaba con tal información, no era del todo correcta y creo que más le preocupaba tener una norma explicita que declare todo el mecanismo para levantar el secreto bancario, de tal manera que como país cumplamos con la regulación internacional.

Asimismo, los cambios normativos promulgados cumplen para postular al Perú a la Organización para la Cooperación y el Desarrollo Económico - OCDE, pues este Organismo Internacional no solo pone como requisito el levantamiento del secreto bancario sino también el levantamiento a la reserva tributaria, el libre acceso a la información entre países, entre otros.

Por tanto, considero que ha sido importante fortalecer a la UIF pero como comenté líneas arriba, esas normas fueron un formalismo pues en la práctica los Oficiales de Cumplimiento reportan en sus operaciones sospechosas los pasivos y activos de los clientes. Otro punto a destacar es que se extiende la lista de Sujetos Obligados incluyendo a los abogados y contadores, lo cual me parece muy importante pues ayudaría a tener mapeadas todas las transacciones que hagan los clientes de estos profesionales, sin embargo tendrá que verse en la práctica como la UIF aplicará supervisiones a estos profesionales pues ellos manejan la confidencialidad y el secreto profesional que tienen con sus clientes. 
c) Debida seguridad en la confidencialidad y reserva del nombre del Oficial de Cumplimiento:

En la actualidad presenciamos que las investigaciones nacen en un cuarto poder denominado "el periodismo". Los medios de comunicación se nutren de información y la publicación pues es su deber y función pero el difundir casos emblemáticos ocurridos en nuestro país, donde nombran a instituciones financieras hacen que la función del Oficial de Cumplimiento se vea vulnera para ellos y “presa fácil” para los que delinquen pues estas personas mediante la prensa, toman conocimiento de su delator. He aquí la importancia de las autoridades (Policía Nacional, Ministerio Público y Poder Judicial) en no difundir los informes emitidos por la Unidad de Inteligencia Financiera, debido a que esos informen se inician ante un reporte comunicado por algún Sujeto Obligado.

Considero de suma importancia, que nuestras autoridades tomen conciencia de la importancia del deber de reserva y confidencialidad de la información que manejan y no difundirla. Asimismo, debemos implementar una cultura de compliance con el objetivo de que si se pone ha descubierto el nombre del Oficial de Cumplimiento, los medios de comunicación sean conscientes en no divulgar la información por las consecuencias funestas que pueden sufrir en las labores de personas que trabajan en una institución privada y que no cuentan con protección física o jurídica como si la tiene una autoridad.

El Martes 28 de febrero de 2017, se realizó la presentación del Estudio de Integridad en el sector público peruano, donde la OCDE - Organización para la Cooperación y Desarrollo Económico, presentó su informe que contienen el análisis del desarrollo de las funciones de públicas en nuestro país en materia de corrupción y otros aspectos.

En el citado informe, la OCDE entre varias recomendaciones, señala que se debe reforzar la protección a los denunciantes, si bien es cierto existe la figura del colaborador eficaz, el nombre de esa persona siempre es conocida por todo el público en general, por tanto se deben mitigar estos riesgos para que se busque la 
contribución de los ciudadanos a que denuncien conductas dolosas de los funcionarios públicos.

Realizo el presente comentario debido a que si los mismos Fiscales y Jueces no cumplen con resguardar el nombre del colaborador eficaz, entonces el nombre del Oficial de Cumplimiento, que no es parte del ámbito fiscal o judicial, es divulgado sin medir las consecuencias fatídicas para esa persona.

d) Incluir como responsables en la debida aplicación de los sistemas de prevención de lavado de activos a las sociedades auditoras externas:

Otra mejora planteada en el presente trabajo, es sobre la actuación de las sociedades auditoras externas y la importancia que deben tener sus informes en todos los ámbitos de una empresa.

Sabemos que los auditores externos realizan evaluaciones principalmente a los aspectos contables y financiero dentro de una empresa, de ese modo-también la norma los regula para el caso de los sistemas de prevención de lavado de activos. Es por ello, que bajo mi óptica y experiencia, considero que los auditores externos no están cumpliendo el rol que se les encomienda y asimismo no existe una norma legal específicamente en el ámbito legal que los haga responsables por los informes que emiten.

En ese sentido, como mejora planteo la inclusión de los auditores externos a fin de que junto con el Oficial de Cumplimiento sean responsables por los informes que emiten, la obligatoriedad de las empresas financieras en contratar auditorías externas de firmas internacionales costosas, han hecho que en el mercado abunden informes pero que éstos documentos no tengan la relevancia e importancia que deberían tener.

En consecuencia a ello, el incluir penalmente a los auditores externos ante una investigación de lavado de activos sería fundamental para darle mayor importancia a sus evaluaciones y que sus informes no sean un copiar y pegar del informe emitido en años anteriores. 
Cabe indicar que los auditores externos cumplen un rol importante dentro de las líneas de defensa de todas las instituciones pues su labor es detectar y observar las falencias o debilidades de los sistemas de prevención de lavado de activos, lo que resultaría ser un soporte y respaldo para el cumplimiento de las funciones de los Sujetos Obligados.

e) Equilibrar la responsabilidad penal del Oficial de Cumplimiento hacia los funcionarios comerciales que conocen y vinculan a los clientes:

Lo que se trata en este trabajo, no es eliminar la responsabilidad penal del Oficial de Cumplimiento, sino de establecer un marco legal bien definido pues se trata de privar la libertad de una persona, que en algunos casos no ha participado en el acto doloso. En ese marco, es imprescindible eliminar la responsabilidad culposa del Oficial de Cumplimiento o en su defecto, modificar el marco normativo actual que es el artículo $5^{\circ}$ del DL 1106.

En ese orden de ideas, es que planteo incluir también a los funcionarios comerciales de las instituciones financieras, pues como ya se explicó, ellos son los funcionarios que traen a los clientes y que los acompañan durante toda su estadía dentro de las instituciones. El funcionario comercial es quién le ofrece los productos y servicios que ofrecen los Bancos y por tanto tiene conocimiento a quien y porque se los está ofreciendo. Incluir a estos funcionarios sería un buen paso para fortalecer los sistemas de prevención de lavado de activos pues desde el Conocimiento del Cliente se realiza/la detección de una operación sospechosa, el Oficial de Cumplimiento es quien detecta la operación inusual y se soporta dentro de sus investigaciones en el Funcionario Comercial, pues el Oficial de Cumplimiento no puede tener contacto con el cliente.

Y si el Comercial se encuentra enlazado con el cliente en lavar dinero dentro de la institución entonces va ser muy fácil que pueda mentir al Oficial de Cumplimiento sobre las operaciones que está realizando el cliente investigado pues lo va a encubrir. Si no se incluye a estas personas dentro del ámbito penal no va ser 
posible que el Oficial de Cumplimiento pueda ejercer sus labores de manera eficiente.

Cabe resaltar, que la norma de lavado de activos (Res. SBS 2660-2015) establece responsabilidades para el Gerente General y para el Directorio del Banco, asimismo la Ley General de Sociedades también presenta la responsabilidad penal de la Gerencia General, sin embargo no existe ninguna norma que involucre también a los funcionarios comerciales quienes son los que traen clientes a los Bancos, es por ello que considero la importancia de incluir a este tipo de funcionarios pues también forman parte del sistema de prevención de lavado de activos de las instituciones.

f) Implementar en el Perú la función del Compliance Officer como se realiza en Canadá y USA:

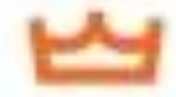

Las normas anglosajonas en temas relacionados al lavado de activos están direccionadas a un conjunto normativo diferente al que tenemos en nuestro ordenamiento jurídico, es por ello que en Estados Unidos o Canadá el concepto y funciones del Compliance Officer abarcan las áreas penal, prevención de lavado de activos, fraudes, prevención del terrorismo, corrupción y cümplimiento de normas regulatorias en general.

El Compliance Officer en una institución financiera tiene la misma jerarquía o hasta podría decir que una mayor relevancia que el Auditor Interno, pues a diferencia de éste último, su función va más allá en la medida que se encarga de detectar y reportar a las autoridades Lsobre las personas que se encontrarían delinquiendo dentro de su institución, en cambio el Auditor Interno no debe reportar a ninguna autoridad sobre las observaciōnes que deteeta, sino más bien su función es interna dentro de una institución.

El Auditor Interno realiza un control sobre los procesos que llevan a cabo para que la empresa cumpla con sus funciones, ante fallas lo que hace es evidenciar e imponer observaciones o recomendaciones para que éstas sean subsanadas, 
asimismo el Auditor Interno no carga una responsabilidad penal por su trabajo y solo rinde cuentas ante el Directorio de una institución; en cambio el Oficial de Cumplimiento responde penalmente sobre sus actos o en muchos casos por actos que no hizo, es decir el reportar una operación sospechosa puede traer los resultados siguientes:

- Puede ser llamado a declarar en una investigación para que expliqué por qué reportó la operación sospechosa.

- Puede ser incluido dentro de una investigación para evidenciar que reportó una operación sospechosa.

- Puede ser víctimà de amenazas o atentados contra su vida por el cliente que ha sido reportado.

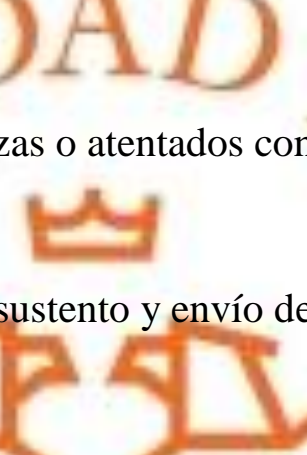

Asimismo, el no reportar una operación sospechosa puede traer las consecuencias siguientes:

Puede ser llamado a declarar en una investigación por no reportar la operación.

- Puễde ser incluido dentro de una investigación por no reportar lå̃ operación.

- Puede ser víctima de amenazas o atentados contra su vida por el cliente que ha sido reportado.

- Es responsable penal por el sustento y envío de un reporte de operación sospechosa.

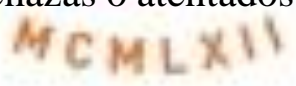

- Es responsable penal por el sustento y envío de un reporte de operación sospechosa. 
1. Instruir a las autoridades fiscales y judiciales sobre la confidencialidad y reserva de la investidura del Oficial de Cumplimiento:

Como comenté líneas arriba, el Oficial de Cumplimiento es un ejecutivo de una entidad privada y su función no es perseguir la acción penal pues esa obligación la tienen las autoridades correspondientes, sin embargo los fiscales o jueces pretenden comprometer al Oficial de Cumplimiento haciéndolo partícipe de sus investigaciones, lo que resultaría en exponer el nombre del funcionario bancario dejándolo al descubierto y que se pierda la confidencialidad y reserva del informe de operación sospechosa emitido por el funcionario que trabaja en un Banco.

Asimismo, ocurre por ejemplo con los casos del "colaborador eficaz", quienes son personas anónimas que denuncian hechos delictivos y que deben ser encubiertos para cubrir su identidad y vida, sin embargo los nombres de estas personas son de conocimiento público en los medios de comunicación.

Es por ello, que los fiscales o jueces tienen el deber de resguardar celosamente la información que les proporciona la Unidad de Inteligencia Financiera, pues divulgar la fuente bancaria que reportó la operación sospechosa, lo único que va a realizar, es que el Oficial de Cumplimiento no reporte operaciones sospechosas para salvaguardar su integridad y por lo contrario podrá ejercer dos opcionês:

a) Desvincular al cliente de su institución sin reportarlo y/o no reportar la operación sospechosa y

b) Tomar otros mecanismos que cubran su función, como por ejemplo capacitar al funcionario de la cuenta o no reportar la operación, lo cual contribuiría a que el delincuente siga lavando dentro de su institución sin reportar tales acciones a las autoridades pertinentes.

De acuerdo a lo comentado, es importante recalcar la responsabilidad de las autoridades en cuanto al apoyo que le deben de brindar a todos los Sujetos Obligados, debido a que deben custodiar celosamente los informes que la Unidad de 
Inteligencia les entrega pues estos informes se originan en los reportes de operaciones sospechosas de los Oficiales de Cumplimiento de los Bancos.

Asimismo, los fiscales y jueces deben de tener como aliados a los funcionarios bancarios, debido a que somos nosotros quienes manejamos la información de los clientes y siempre debemos estar dispuestos por iniciativa propia a evitar este tipo de actos ilícitos, sin embargo de presentarse una coyuntura en la que no existe seguridad para los Oficiales de Cumplimiento entonces éstos no reportaran operaciones sospechosas y tratarán de desvincular al cliente de su institución sin tener que remediar con autoridades judiciales que expondrán su nombre ante las partes involucradas en una investigación penal o en los medios de comunicación.

Finalizando el tercer capítulo, a continuación se presenta la entrevista al Notario Público de Lima - Sr. Marco Antonio Becerra Sosaya, con la finalidad de conocer su punto de vista sobre los temas tratados en el presente capítulo.

\section{Entrevista al Dr. Marco Antonio Becerra Sosaya - Notario Público de Lima:}

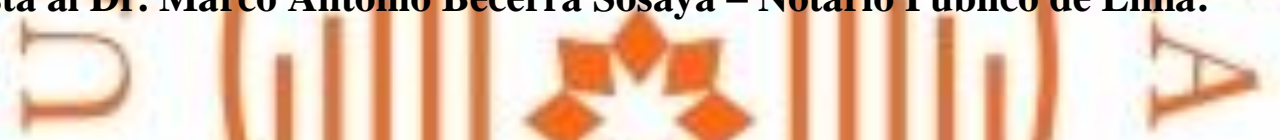

1. Existe una verdadera protección a los Oficiales de Cumplimiento, en cuanto a la reserva y confidencialidad sobre su nombre y funciones?

Definitivamente, la confidencialidad en la identificación del oficial de cumplimiento, así como sus comunicaciones están sometidas al deber de reserva. Este es un aspecto medular que caracteriza la función del oficial, pues de no ser así, estaría expuesto por un lado en el ámbito personal y familiar en cuanto a su seguridad, y por otro lado, podría estar sujeto a presiones y amenazas de las mafias que lavan activos.

En lo referente a los notarios, somos sujetos obligados a informar a la UIF y entre nuestros deberes está la designación de un oficial de cumplimiento, el cual cuenta con un código de identificación que favorece el no reconocimiento del oficial por su nombre. Asimismo, cuando dicho oficial envía a la UIF el reporte de alguna operación que le parece sospechosa, tal comunicación también está encriptada por un código. Siendo así, es dable 
concluir que a nivel de la UIF sí existen las bases normativas para que se mantengan en reserva estos aspectos.

El problema se produce cuando dejamos la esfera administrativa y nos adentramos en los fueros del Ministerio Público y el Poder Judicial: Ha sucedido en no pocas ocasiones, que a los oficiales de cumplimiento se les llama a declarar como testigos, identificándolos por sus nombres y notificándoles a sus respectivos domicilios.

Esto atenta no solo contra el espíritu que informa toda la normativa en materia de lavado de activos, sino que además pone en serio peligro la integridad física de quienes ostentan la posición de un oficial de cumplimiento. Tan cierto y tan recurrente es lo dicho, que el Poder Judicial se ha visto en la necesidad de emitir la resolución administrativa $\mathrm{N}^{\circ}$ 467-2012-PJ (Acuerdo Plenario 03-2010), en virtud a la cual se establece con carácter vinculante para todas las instancias de dicho poder del Estado el tratamiento y participación secreta y encriptada de los oficiales de cumplimiento en los procesos judiciales en los que participen.

\section{Considera usted que se debe eliminar la Responsabilidad Penal por Culpa del Oficial de Cumplimiento? Qué ventajas o desventajas cree Usted que pueda generar en el sistema de prevención de LAFT la eliminación de la Responsabilidad por Culpa del Oficial de Cumplimiento?}

Para responder esta pregunta hay que partir por dejar bien establecido, que el Oficial de Cumplimiento es el actor principal en la lucha contra el lavado de activos. El legislador ha querido dejar en sus hombros la responsabilidad de identificar aquellas operaciones que tengan visos de ilegalidad vinculados a esta modalidad delictual.

Esto prima facie es correcto, pues sin perjuicio del nombre o denominación que adopte, debe existir un responsable en los fueros de cada sujeto obligado, que responda ante la autoridad estatal -en este caso, la UIF-, por la identificación de esas operaciones que podrían entrañar cierta ilegalidad bajo la modalidad que venimos comentando.

Bajo esta premisa, el grado de responsabilidad del oficial de cumplimiento se puede medir de tres formas: a) laxamente; b) rígidamente; o, c) de forma intermedia. Si 
adoptamos una posición laxa, es decir, si optamos por atribuir responsabilidad al oficial solo cuando la operación involucra notoria y contundentemente un lavado de activos, estaríamos generando un efecto contraproducente, pues en materia de incentivos negativos, el oficial de cumplimiento dejará pasar muchas operaciones dudosas apelando a que no constituyen notoriamente lavado de activos.

En la otra acera, es decir, si responsabilizamos al oficial de cumplimiento rígidamente, atribuyéndole responsabilidad por aquellas operaciones que incluso podrían pasar por ordinarias pero que tienen un ligero tufillo de lavado de activos, generaremos también un efecto adverso, pues dicho oficial reportará a la autoridad todas las operaciones que se le presenten incluso más allá de un margen de razonabilidad, a fin de evitar pecar por omisión; con ello, la UIF contará con reportes que impliquen cientos de miles de operaciones sin discriminar, con la consecuencia nefasta de no poder identificar las verdaderas operaciones que implican lavado de activos por imposibilidad logística y de recursos humanos.

Siendo así, la medición de responsabilidad de los oficiales de cumplimiento debe ser intermedia o ecléctica. En el ámbito civil y administrativo y a la luz de la explicación que antecede, consideramos que la responsabilidad del oficial de cumplimiento debe ser por culpa inexcusable.

En el ámbito propiamente penal debo dejar paso a los especialistas en dicha materia, esperando que el modesto análisis que antecede pueda contribuir a esclarecer la respuesta.

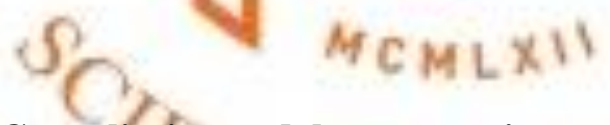

\section{El Oficial de Cumplimiento debe ser un investigador privado o un funcionario bancario que implemente un sistema de prevención de lavado de activos?}

Definitivamente el oficial de cumplimiento no puede ser un investigador privado, pues de ser así se generarían dos consecuencias harto discutibles: La primera es que su ámbito de acción no estaría adecuadamente delimitado y por tanto, algunos oficiales podrían actuar excediendo el marco de sus funciones, y otro más bien actuarían en menos de lo que se espera de su función. Y la segunda es que, al no estar correctamente delimitada su función, el ámbito de responsabilidad no estaría adecuadamente definido y quedaría al mero arbitrio 
de cada autoridad en particular decidir si hay o no responsabilidad en el accionar del oficial, lo cual lo coloca en una posición muy vulnerable.

Por tanto, antes que un investigador privado, el oficial de cumplimiento es el responsable de que se implemente adecuadamente en el banco (para el caso que nos ocupa), el sistema de prevención der lavado de activos.

Conforme a lo sostenido hasta aquí, debe quedar claro para la entidad financiera que, dada la responsabilidad que ostenta el oficial de cumplimiento frente a las autoridades estatales, la entidad está obligada a implementar todas las acciones complementarias a las desarrolladas por ésta que sean recomendación del oficial de cumplimiento; es decir que, el oficial no es un mero actor pasivo que se limita a adecuar su trabajo al sistema desarrollado e impuesto por el banco; más bien, a partir de ese sistema, está obligado a proponer mejoras al mismo.

El resultado final importa contar con un sistema de prevención de Tavado de activos claro y con reglas objetivas; solo así podremos definir contundentemente el ámbito de actuación del oficial de cumplimiento para que este no sea bajo ningún punto un investigador privado.

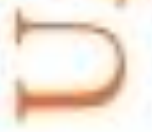

\section{En caso se otorgue a la UIF la facultad para poder levantar el secreto bancario de} las personas, cree Usted que esta medida fortalecerá los sistemas de prevención de lavado de activos?

Definitivamente el levantamiento del secreto bancario es una herramienta eficaz y a nuestro juicio harto recomendable en este afán de dar dura lucha al lavado de activos.

Hay que tener en cuenta empero, que el secreto bancario es una garantía constitucional y por tanto es un derecho subjetivo digno de una protección a ultranza.

Conforme a ello, bajo el escenario que supone otorgar la facultad a un ente estatal de levantar el secreto bancario, nos encontramos que en la balanza están contrapuestos dos derechos de capital importancia en una democracia: por un lado, la garantía de todo ciudadano de gozar del secreto bancario, y del otro, el derecho de la sociedad en pleno a 
combatir el lavado de activos, el cual afecta -entre otros- la macroeconomía de un país, y como reflejo la economía de cada persona.

Es decir que, si asumimos posición en pro de levantar el secreto bancario debe quedar claro que estamos eventualmente y estando en el marco de las investigaciones, vulnerando un derecho constitucional, para dar preferencia a otro. En esa medida, consideramos que dicha vulneración solo puede ser efectuada por un órgano que cuente con todas las herramientas para analizar los indicios que pueden llevar a levantar el secreto bancario de un ciudadano. Dicho ente a nuestro parecer no puede ser la UIF pues se trata de un ente administrativo, cuyas herramientas ciertamente son limitadas, en comparación al Poder Judicial. No olvidemos que los jueces cuentan con un ámbito de discrecionalidad que informa su labor y que a la luz de un criterio razonable otorga mayores garantías a los ciudadanos.

En atención a lo hasta aquí mencionado, estamos a favor del levantamiento del secreto bancario en el escenario de la lucha contra el lavado de activos; sin embargo, creemos firmemente que es el Poder Judicial quien tiene que contar con dicha prerrogativa y no la UIF.

\subsection{Conclusiones del tercer capítulo}

- En el presente capítulo he explicado los resultados que implicaría realizar la modificación normativa planteada, debido a que si las autoridades apoyan las labores del Oficial de Cumplimiento, resguardando su identidad o manteniendo en total reserva y confidencialidad los reportes de operaciones sospechosas, podremos detectar lavadores que se encuentran inmersos en estos momentos en el sistema financiero peruano.

- Asimismo, considero importante que los legisladores quienes son los que emiten las normas, deben conocer el tema o deben acercarse al sector privado a fin de buscar asesoría con el objetivo de que puedan emitir normas claras que ayuden verdaderamente a la prevención del lavado de activos. 
- Finalmente, puedo concluir que los Oficiales de Cumplimiento del sistema financiero se encuentra capacitados y respaldados por las empresas bancarias donde trabajan y que la contingencia que existe en la actualidad se encuentra en los sectores no regulados como son las cooperativas y también en la mayoría de Sujetos Obligados que no le están dando la real importancia dentro de sus empresas en implementar un sistema de prevención de lavado de activos.

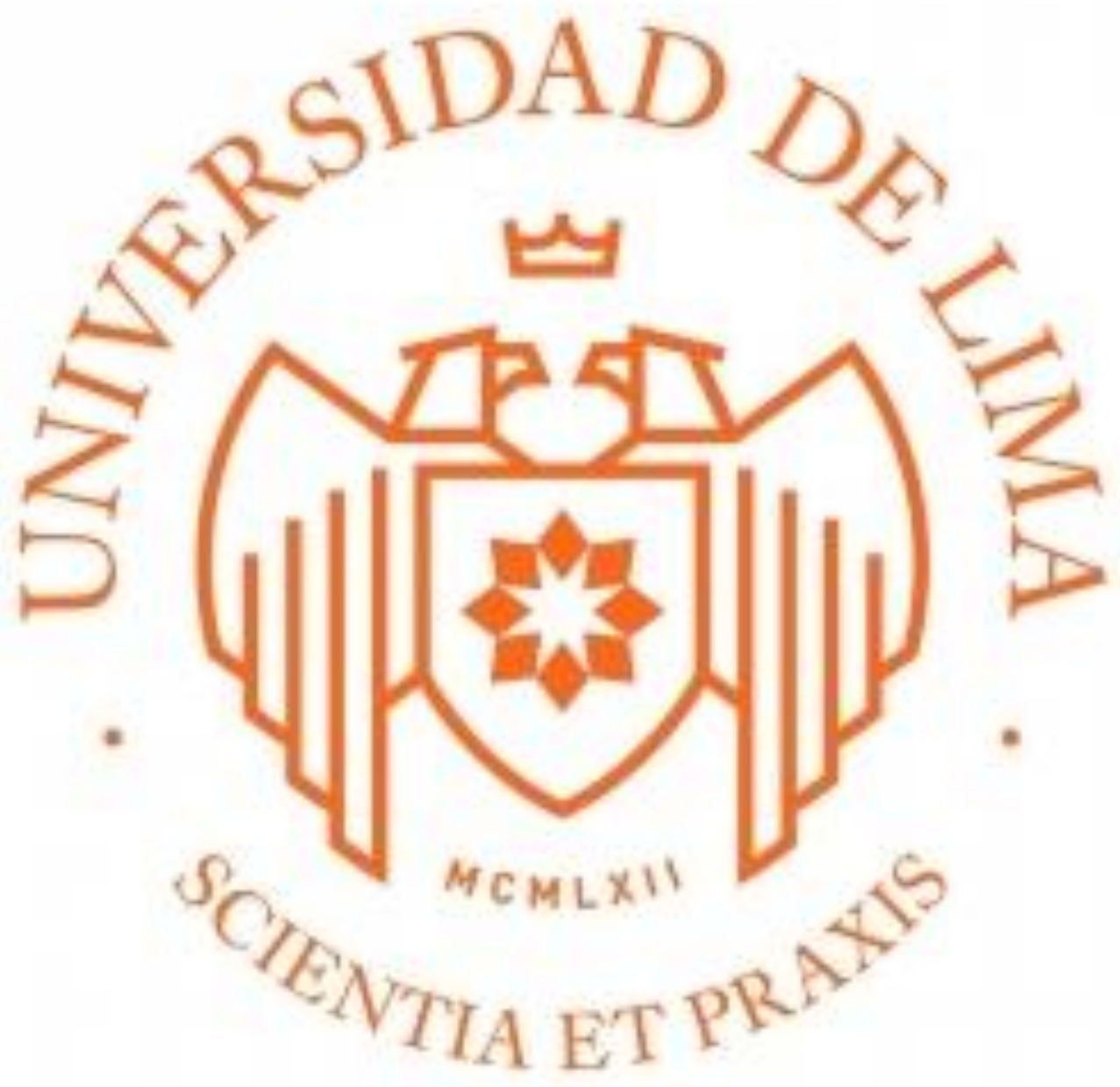




\section{CONCLUSIONES}

Dados los puntos expuestos en el presente documento, puedo concluir que a nivel Perú se han dictado normas importantes para evitar el blanqueo de dinero en nuestro país, normas que van de la mano con la regulación internacional y que son fundamentales también para nuestra entrada a la OCDE - Organización para la Cooperación y el Desarrollo Económicos. En ese orden de ideas, en la actualidad existen organismos internacionales como la Oficina de control de Activos Extranjeros de Estados Unidos - OFAC o el Grupo de Acción Financiera -GAFI destinados a combatir el lavado de activos y el financiamiento del terrorismo a nivel mundial, donde el Perú se encuentra alineado a ese fin.

Es por lo antes expuesto, la importancia de la función de los Oficiales de Cumplimiento, y más aun los que son funcionarios bancarios, pues las organizaciones delictivas necesitan introducir el dinero ilícito en el sistema financiero para poder operar. En consecuencia a ello, si el Oficial de Cumplimiento se encuentra desprotegido y puede ser un blanco fácil para los lavadores de dinero, no realizarán sus funciones con la eficiencia e importancia que tiene su rol, pues el reporte de una operación sospechosa es el inicio para una investigación que puede llegar a desbaratar a una organización criminal.

Es importante indicar también, que los Oficiales de Cumplimiento simplemente son funcionarios dentro de una institución y no se les puede adherir funciones que les corresponde a un fiscal o juez, pues ser funcionario bancario por ejemplo, implica estar alineado a los objetivos del Banco, es decir objetivos que tienen por finalidad hacer que el Banco crezca comercialmente, captando nuevos clientes, obteniendo fondeo y prestando el dinero de sus clientes para obtener ganancias.

En ese sentido, la función del Oficial de Cumplimiento es apoyar a la empresa en que labora a que crezca, de tal manera que sea una empresa rentable para los accionistas y para los trabajadores, es por ello que el Oficial de Cumplimiento tiene la función de ser un control interno más, al igual que el Auditor Interno, y si pretendemos que el Oficial de 
Cumplimiento cierre cuentas, reporte a sus clientes a la UIF, terminaríamos haciendo que el negocio quiebre.

De lo expuesto, los Sujetos Obligados cumplen con su rol de reportar ciertas operaciones sospechosas de acuerdo a su criterio y al apetito de riesgos que tenga la institución donde labora, sin embargo equivocadamente se cree que el Oficial de Cumplimiento tiene la obligación de reportar "todo lo que sea" o bien podemos comentar la siguiente frase: "ante la duda mejor reporta", lo que es fatal no solo para las empresas sino también para las mismas autoridades, pues se le estaría facultando poderes a un funcionario que no le corresponden.

En el caso, que exista una investigación de lavado de activos a nivel fiscal de una persona que tenga cuentas en un Banco X, el fiscal no puede incluir en la investigación al Oficial de Cumplimiento del Banco X, solo por el hecho de que ese Oficial de Cumplimiento no reporto operaciones sospechosas que a "criterio" del fiscal si debió reportar. En este supuesto la Res. SBS 2660-2016 es clara y a continuación copio el extracto de la norma:

Artículo $29^{\circ}$.- Etapas de la debida diligencia en el conocimiento del cliente

29.2 Cuando la empresa no se encuentre en la capacidad de cumplir con las medidas de debida diligencia en el conocimiento del cliente debe proceder de la siguiente manera: i) no iniciar relaciones comerciales, no efectuar la operación y/o terminar la relación comercial iniciada; y/o ii) evaluar la posibilidad de efectuar un reporte de operaciones sospechosas (ROS) con relación al cliente.

29.3 En caso la empresa tenga sospechas de actividades de LA/FT y considere que el efectuar acciones de debida diligencia alertaría al cliente, debe reportar la operación sospechosa a la UIF-Perú/sin efectuar dichas acciones. Estos casos deben encontrarse fundamentados y documentados.

Es importante analizar las palabras que he subrayado y he sombreado en negro, pues son conceptos que dejan al libre criterio del Oficial de Cumplimiento y de la institución donde labora éste, sobre la posibilidad de reportar una operación sospechosa.

En ese orden de ideas, una autoridad judicial o autoridad administrativa se ve impedida de castigar o llamar la atención a un Oficial de Cumplimiento por no reportar una operación 
sospechosa, debido a que la norma desprende y deja al criterio y sentido común del Oficial de Cumplimiento continuar con la relación comercial o no que mantiene con su cliente.

Este aspecto es muy importante, dado que Constitucionalmente todas las empresas tienen la libertad de hacer negocios, tal y como se evidencia en el artículo $59^{\circ}$ de nuestra Constitución:

Artículo $59^{\circ}$.- El Estado estimula la creación de riqueza y garantiza la libertad de trabajo $\mathbf{y}$ la libertad de empresa, comercio e industria. El ejercicio de estas libertades no debe ser lesivo a la moral, ni a la salud, ni a la seguridad pública. El Estado brinda oportunidades de superación a los sectores que sufren cualquier desigualdad; en tal sentido, promueve las pequeñas empresas en todas sus modalidades.

En consecuencia a ello, la libertad de los Bancos de hacer dinero es una garantía constitucional que se encuentra respaldada, por tal motivo el pretender intimidar a los Oficiales de Cumplimiento para que reporten un mayor número de operaciones sospechosas de sus clientes afectaría directamente el derecho que tienen todas las empresas al libre ejercicio del comercio y a ganar la mayor rentabilidad posible.

En ese sentido, lograr eliminar la responsabilidad culposa del Oficial de Cumplimiento, consolidaría su función, enervaría su obligación de enviar reportes consolidados a las autoridades y entes reguladores, de tal manera que pueda presentar pruebas fundamentales a fin de evitar actos delictivos como es el lavado de dinero.

Sin embargo, es importante indicar, que los Oficiales de Cumplimiento son funcionarios bancarios o de la empresa a la cual pertenezcan y no son autoridades o policiales que tienen la obligación de detectar delincuentes dentro de sus instituciones, esas funciones son exclusivas de las autoridades (policía, fiscales y jueces), por ende la labor del Oficial de Cumplimiento se centra principalmente en implementar un sistema de prevención de lavado de activos, cumplir con las normas regulatorias y dar cuenta de su trabajo al Directorio de su institución que son los encargados de supervisar la labor del Oficial del Cumplimiento.

En consecuencia a lo antes descrito, para realizar una verdadera Prevención del Lavado de Activos en nuestro país, pienso que afianzar los siguientes temas nos ayudarán a evitar que el delito de lavado de activos crezca en el Perú: 
- Cultura de Cumplimiento: Crear una cultura de Cumplimiento dentro de la organización, concientizaría a todos los trabajadores a prevenir el lavado de activos; sin embargo recomendaría no solo enfocarnos en el delito de lavado de activos, sino en los delitos precedentes que conllevan a lavar dinero.

- Compliance Officer: Fortalecer la investidura del Oficial de Cumplimiento y unificar dentro de sus competencias áreas como: legal, fraude y control normativo, con la finalidad de uniformizar las áreas de soporte de prevención de las instituciones y no que cada una actúe por su lado.

- Marco normativo real: Hoy en día encontramos muchàs normas dispersas sobre la prevención del Tavado de activos, recomendaría consolidar las normas en un solo cuerpo normativo con la finalidad de no encontrar diferentes opiniones o interpretaciones según las conveniencias de cada caso.

- Sujetos Obligados libres de reportar sin miedos: De realizarse la modificación normativa planteada, respaldaría las funciones y responsabilidades del Oficial de Cumplimiento, lo que resultaría en la emisión de reportes de operaciones sospechosas de mejor calidad y de verdadera investigación.

- Autoridades responsables: Solicitar a la Policía, Fiscales y Jueces mayor profesionalismo en sus funciones, mayor coordinación entre ellos y que velen por la información confidencial que obran en los reportes de operaciones sospechosas.

- Modificación del Artículo 5 del DL 1106: Lograría combatir fehacientemente el delito de lavado de activos, pues los responsables de la implementación de los sistemas de prevención de lavado de activos, tomarían mayor seriedad sobre sus obligaciones.

- Capacitaciones: No solo tener un Plan de Capacitaciones por cumplir, sino ejercer un rol de seguimiento y puesta en práctica sobre las capacitaciones que se dicten dentro de una organización. 


\section{REFERENCIAS}

Albrecht, H. (2001).Criminalidad transnacional, comercio de narcóticos y lavado de dinero. Traducción: Óscar Julián Guerrero Peralta, Bogotá: Universidad Externado de Colombia.

Ambos, K., Caro, C. y Malarino, E. (Abril 2015).Lavado de Activos y Compliance. Perspectiva internacional y Derecho Comparado. Jurista Editores EIRL.

Apolaya S., L. (2006). Estudio exploratorio de las causas que influyen en el uso del sistema financiero. Lima.

Aránguez Sánchez, C. (2000). El delito de blanqueo de capitales, Barcelona: Marcial Pons.

Badwin, F. (1998).Money laundering, asset forfeiture and international financial crimes, New York: Ocean Publication.

Blanco Cordero, I. (1999). Responsabilidad penal de los empleados de banca por el blanqueo de capitales, Granada Editorial Comares SL. España

Bustos Ramírez, J. (1994). Manual de Derecho Penal, parte general. P.P.U. Barcelona.

Caro Coria, C. (2012). Sobre el tipo básico de lavado de activos, ADPE - Anuario de Derecho Penal Económico y de la Empresa. Lima

De La Haza Barrantes, A. (2006). Oficial de Cumplimiento o Conejillo de indias en el tema de Prevención de Lavado de Activos en el sistema financiero nacional. Artículo publicado por la revista Ius Praxis de la Facultad de Derecho de la Universidad de Lima.

Diario La República, (2003). PNP investiga hijo de Schutz por sospechas transferencias de dinero. Recuperado de: http://larepublica.pe/10-05-2003/pnp-investiga-hijo-deschuetz-por-sospechosas-transferencias-de-dinero

Diaz, J. M. (30 de octubre del 2007). Investigan cuentas del Banco Continental. Panamá América. Recuperado de: http://www.panamaamerica.com.pa/content/investigancuentas-del-banco-continental

García Cavero, P. (2001). El delito de lavado de activos, cit.: García Cavero: El delito de lavado de activos. Lima.

García Cavero, P. (2007). Derecho penal económico. Parte especial II, cit.: García Cavero: Derecho Penal Económico P. E, Lima. 
Muñoz Conde, F y García Arán, M. (2002). Derecho Penal parte general. 5ta edición, Valencia.

Pinilla Pinilla, N. (2003).Observaciones sobre la propuesta de reforma a los delitos de lavado de activos y omisión de control. Editorial Vniversitas, Colombia

Prado Saldarriaga, V. R. (2007). Los delitos Periféricos al Lavado de activos en el Decreto Legislativo 1106. Idemsa. Lima.

Revista de Derecho Penal y Criminología. (1998) Del Instituto de Ciencias Penales y Criminológicas de la Universidad de Externado de Colombia. No. 67

Roxin, Claus (2002). Derecho Penal, parte general. Tomo I: Fundamentos de la estructura del delito. Editorial Civitas, S.A. Madrid

Superintendencia de Banca, Seguros y Afp. (2003).Texto concordado de la Ley General del Sistema Financiero y del Sistema de Seguros y Ley Orgánica de la Superintendencia de Banca y Segurôs. Pie de Imprenta: Lima: SBS.

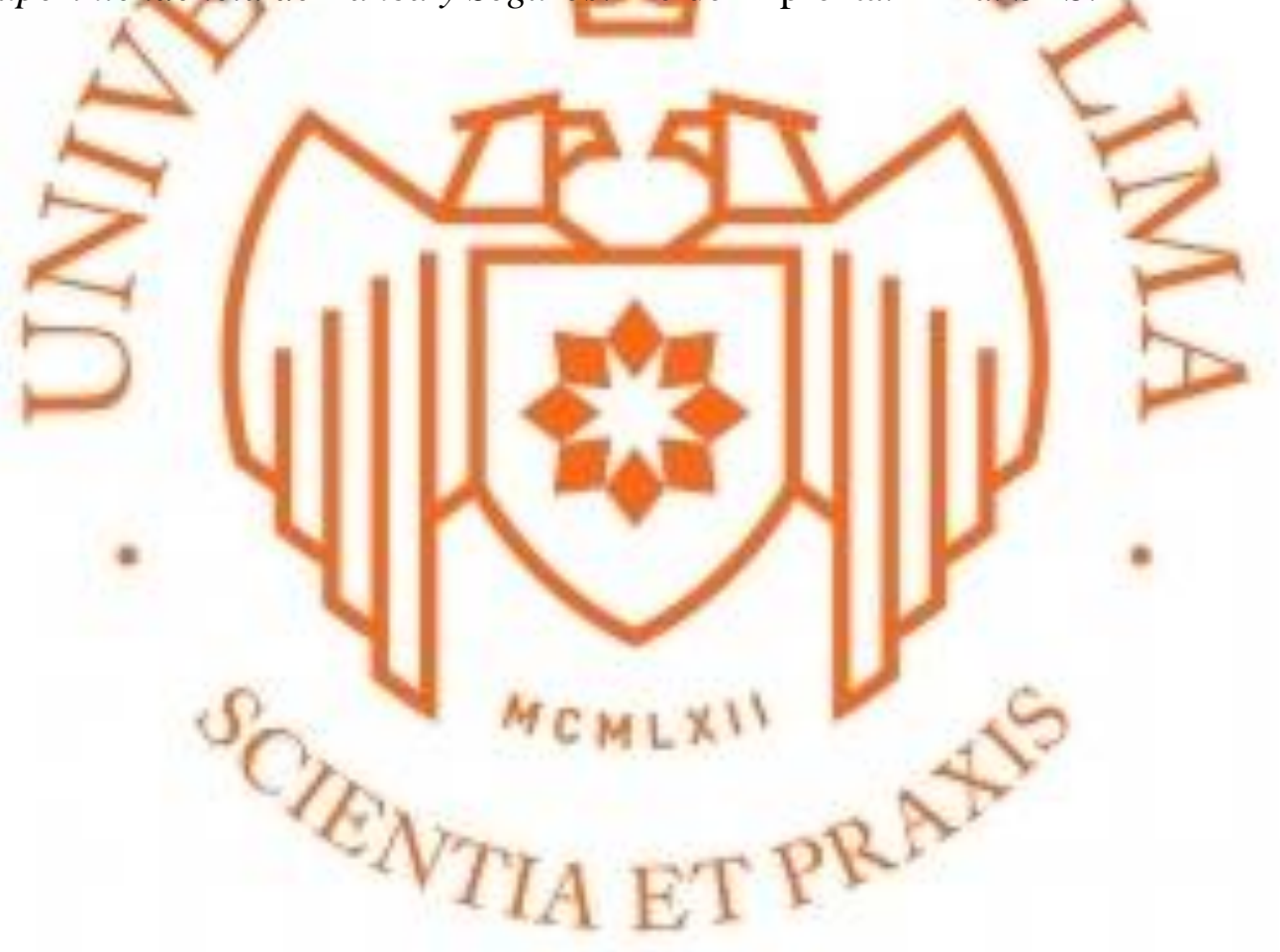

